\title{
REKONSILIASI DATA KEUANGAN DAN KARAKTERISASI SATUAN KERJA DENGAN TEKNIK DATA MINING
}

\author{
Dedy Elisa Limbong \\ Direktorat Akuntansi dan Pelaporan Keuangan \\ Alamat Korespondensi: dedyelisalimbong@gmail.com
}

\section{INFORMASI ARTIKEL}

Diterima Pertama

13 Juni 2016

Dinyatakan Diterima

14 November 2016

\section{KATA KUNCI:}

Central Government Financial

Reporting, State General Treasurer, Accounting System, Data Mining Techniques, Financial Data Reconciliation.

KLASIFIKASI JEL:

H83.

\begin{abstract}
ABSTRAK
The central government is responsible for central government financial reporting, and the preliminary step of which is the reconciliation of financial data between the State General Treasurer (BUN) at KPPN and the Spending Units (Satker). The Supreme Auditor (BPK) found unmatched reconciliation of financial data in the accounting system between BUN and Satker. The Directorate General of the Treasury might reduce the possibility of unmatched financial data by conducting supervisory activities based on Satker characteristics. Data mining techniques can be used for selecting data using Sistem Perbendaharan dan Anggaran Negara (SPAN) database. This research uses classification technique by setting two classes, namely SELISIH and $O K$, using 20 attributes of Satker. The results of data mining indicate that Spending Units (Satker), with a high number of Payment Order (SP2D) and non-tax revenue (PNBP) transaction records, tend to have higher possibility of unmatched financial data reconciliation.
\end{abstract}

Penyusunan Laporan Keuangan Pemerintah Pusat merupakan tanggung jawab pemerintah, dan penyusunan laporan keuangan tersebut harus didahului dengan proses rekonsiliasi data keuangan antara Bendahara Umum Negara (BUN) melalui KPPN dengan satuan kerja. Temuan BPK atas selisih hasil rekonsiliasi menjadi bukti bahwa masih terdapat selisih pencatatan akuntansi pada sistem BUN dengan satuan kerja. Direktorat Jenderal Perbendaharaan (KPPN) dapat menekan kemungkinan terjadinya selisih rekonsiliasi dengan melakukan kegiatan supervisi yang terfokus pada karakteristik satker. Teknik data mining dapat digunakan untuk melakukan karakterisasi tersebut dengan memanfaatkan database pada Sistem Perbendaharaan Anggaran dan Negara (SPAN). Teknik data mining dilakukan dengan metode klasifikasi yaitu menetapkan dua kelas yaitu kelas SELISIH dan OK. Penelitian ini menggunakan dua puluh atribut satuan kerja dengan teknik data mining yang hasilnya menunjukkan bahwa satker dengan atribut Jumlah Surat Perintah Pencairan Dana (SP2D) dan Realisasi Penerimaan Negara Bukan Pajak (PNBP) yang tinggi memiliki kecencerungan selisih hasil rekonsiliasi data keuangan. 


\section{PENDAHULUAN}

\subsection{Latar Belakang}

Pertanggungjawaban pelaksanaan APBN dalam pengelolaan keuangan oleh pemerintah pusat diwujudkan dalam Laporan Keuangan Pemerintah Pusat (LKPP). LKPP disusun oleh pemerintah sebagai wujud pernyataan akuntabilitas atas pengelolaan keuangan negara sehingga menjadi kepentingan bagi seluruh rakyat Indonesia, legislatif selaku wakil rakyat, dan bagi pemerintah sebagai sarana evaluasi internal.

Sesuai dengan Peraturan Menteri Keuangan (PMK) Nomor 210 Tahun 2013, penyusunan LKPP dilakukan setelah proses rekonsiliasi data antara Bendahara Umum Negara (BUN) dengan Kementerian/ Lembaga (K/L) selesai dilaksanakan. Rekonsiliasi dilakukan untuk memastikan kebenaran, efektivitas, dan keakuratan penyusunan LKPP. Rekonsiliasi dilakukan dengan cara menandingkan laporan hasil dari sistem yang dimiliki oleh BUN dengan laporan yang dihasilkan oleh sistem Kementerian/ Lembaga.

Dalam pelaksanaannya, proses rekonsiliasi dihadapkan pada selisih pencatatan antara Sistem Akuntansi Umum (SAU) oleh KPPN selaku BUN dengan Sistem Akuntansi Instansi (SAI) yang merupakan pencatatan K/L. Pelaksanaan rekonsiliasi bulanan masih menghadapi permasalahan terkait selisih pada satker-satker tertentu. Hal ini dibuktikan dengan selisih pencatatan yang menjadi temuan Badan Pemeriksa Keuangan (BPK) atas LKPP sejak tahun 2004 sampai dengan tahun 2014 antara lain:

a. Terdapat perbedaan pencatatan belanja antara SAU dengan SAI yang tercermin dalam Suspen Tahun 2013 neto sebesar Rp140.397.661.708 atau absolut sebesar Rp272.905.428.156, dan belum ditindaklanjuti suspen yang terjadi sejak tahun 2004 sampai dengan 2012 (LKPP 2013).

b. Proses rekonsiliasi antara BUN dan K/L tidak efektif sehingga terdapat suspen belanja sebesar Rp557,36 miliar (K/L mencatat lebih besar).

Salah satu tugas dan fungsi KPPN selaku BUN Daerah adalah melakukan pembinaan dan supervisi satuan kerja dalam wilayah kerjanya. Keberhasilan mengidentifikasi faktor-faktor yang mempengaruhi rekonsiliasi dan karakteristik satker dapat mencegah terjadinya selisih, karena KPPN dapat melakukan kegiatan pembinaan yang lebih fokus.

Penentuan karakteristik satuan kerja dan identifikasi faktor-faktor yang mempengaruhi proses rekonsiliasi dapat dilakukan melalui teknik pengolahan (mining) data-data transaksi rekonsiliasi. Penyimpanan database hasil rekonsiliasi dikelola dan ditatausahakan oleh Direktorat Sistem Informasi dan Transformasi Perbendaharaan. Jumlah data dan transaksi rekonsiliasi yang terdiri dari transaksi-transaksi APBN satuan kerja berukuran sangat besar (big data). Data tersebut dapat memberikan informasi tersembunyi yang dapat mendukung pengambilan keputusan.

Data mining merupakan suatu metode yang meliputi proses-proses tertentu untuk menemukan makna-makna dari suatu kumpulan data dalam jumlah besar sehingga dapat menjadi suatu informasi yang dapat dimengerti. Dengan demikian, terdapat dua fokus yang menjadi tujuan dalam penelitian ini, yaitu faktor-faktor yang memengaruhi selisih rekonsiliasi dan karakterisasi satuan kerja.

\section{KERANGKA TEORI DAN PENGEM- BANGAN HIPOTESIS}

\subsection{Sistem Akuntansi dan Pelaporan Keuangan Pemerintah Pusat}

Pemerintah wajib menyusun laporan keuangan sebagai wujud akuntabilitas, pertanggungjawaban kepada masyarakat, dan menjadi alat dalam pengukuran kinerja pemerintah. Dalam menyusun laporan keuangan, pemerintah menyelenggarakan sistem akuntansi sesuai dengan pasal 7 Undang-Undang Nomor 1 Tahun 2004 yang menyatakan bahwa Menteri Keuangan selaku Bendahara Umum Negara (BUN) menetapkan sistem akuntansi dan pelaporan keuangan. Penyusunan laporan keuangan pemerintah mencakup transparansi dan akuntabilitas yang menjadi latar belakang disusunnya sistem akuntansi bagi tiap-tiap entitas baik entitas pelaporan dan entitas akuntansi yaitu antara Bendahara Umum Negara (BUN) dan kementerian/ lembaga.

KPPN selaku UAKBUN-Daerah melakukan penyusunan LKPP tingkat kuasa BUN-Daerah. Laporan Keuangan Pemerintah Pusat (LKPP) tingkat BUN-Daerah disusun setelah KPPN dan satker-satker mitra kerja melaksanakan rekonsiliasi data transaksi antara SAI dan SAU yang merupakan bagian dari Sistem Akuntansi Pemerintah Pusat (SAPP). Selanjutnya LKPP tingkat kuasa BUN-Daerah tersebut disampaikan oleh KPPN kepada UAKBUN-W, UAKBUN-P secara bulanan, semesteran juga tahunan. Kantor Wilayah Ditjen Perbendaharaan selaku UAKBUN-W melakukan penyusunan LKPP tingkat Kuasa BUN Wilayah melalui konsolidasi LKPP seluruh KPPN dalam wilayah kewenangan tiap-tiap kanwil.

Sebagaimana dilakukan pada tingkat kuasa BUN-Daerah, penyusunan LKPP tingkat wilayah 
juga dilakukan setelah rekonsiliasi tingkat wilayah telah dilakukan. Selanjutnya, kanwil selaku UAKBUN wilayah menyampaikan LKPP tingkat wilayah kepada UAPBUN-AP secara triwulanan, semesteran, dan tahunan. UAPBUN-AP kemudian menyampaikan laporan keuangan ke UABUN. Selanjutnya UABUN-Pusat menyusun LKPP tingkat pusat atas seluruh transaksi pengeluaran dan penerimaan. Penyusunan LKPP dilakukan setelah rekonsiliasi tingkat kementerian/ lembaga. LKPP paling tidak meliputi Laporan Arus Kas, Neraca Kas Umum Negara, dan Catatan atas Laporan Keuangan (CaLK).

\subsection{Rekonsiliasi}

Secara umum rekonsiliasi didefinisikan sebagai proses menandingkan hasil-hasil (output) dari berbagai sistem dari input-input dokumen sumber yang sama. Dalam akuntansi komersial dikenal adanya istilah rekonsiliasi bank yaitu proses menandingkan pencatatan kas antara perusahaan dan bank untuk memastikan bahwa tidak terdapat kekeliruan dalam pembukuan pada sistem akuntansi perusahaan dan sistem bank.

Dalam modul tentang rekonsiliasi pada PMK Nomor 210 tahun 2013, dinyatakan bahwa proses rekonsiliasi merupakan hal yang sangat penting dalam menyusun laporan keuangan yang berakuntabilitas. Rekonsiliasi yang efektif akan mendeteksi kekeliruan pencatatan transaksi dalam pembukuan KPPN (BUN) maupun dalam pembukuan satker, sehingga ada mekanisme check and balance yang akan meminimalkan kesalahan. Laporan yang andal dapat memberikan informasi yang berkualitas bagi pembacanya, sehingga pengambilan keputusan-keputusan manajerial dan strategis bebas dari distorsi atas informasi yang tidak valid dan akurat.

Tata cara rekonsiliasi pada tingkat KPPN sebagaimana diatur dalam PMK Nomor 210 tahun 2013 dilakukan antara seluruh satker Unit Akuntansi Kuasa Pengguna Anggaran (UAKPA) dengan KPPN Selaku UAKBUN-D. Proses rekonsiliasi dilakukan atas transaksi-transaksi pelaksanaan anggaran yang meliputi estimasi pendapatan, pagu belanja, realisasi pendapatan dan pengembaliannya, realisasi belanja dan pengembaliannya, uang persediaan, dan transaksi hibah. Hasil rekonsiliasi akan dituangkan dalam Berita Acara Rekonsiliasi (BAR). BAR ditandatangani oleh Kepala Seksi Verifikasi dan Akuntansi KPPN serta Kuasa Pengguna Anggaran tiap-tiap satker setelah hasil rekonsiliasi tidak menunjukkan adanya selisih (sama). Sedangkan terhadap hasil rekonsiliasi yang masih berbeda karena terdapat selisih antara pembukuan KPPN dan satker, BAR dapat diterbitkan sepanjang selisih tersebut dapat dijelaskan secara memadai.

\subsection{Data Mining}

Data mining merupakan suatu metode yang meliputi berbagai proses untuk menemukan makna-makna dari suatu kumpulan data dalam jumlah besar sehingga dapat menarik suatu informasi tersembunyi. Pada dasarnya data mining merupakan ilmu yang menarik perhatian para akademisi dan para peneliti pada beberapa dekade yang lalu. Menurut Mena (1999) yang dikutip oleh Folorunso (2005), data mining merupakan sebuah proses untuk menemukan pola yang dapat dipahami, profil, dan tren tertentu melalui datadata yang dimiliki dengan menggunakan teknologi yang digunakan untuk menemukan pola seperti neural networks, machine learning, dan algoritma genetik. $^{1}$ Sementara itu, Pudjo mengutip David Hand et al. (2012) yang mendefinisikan data mining sebagai suatu analisis atas kumpulan data dalam ukuran besar untuk menemukan hubungan atau pola yang jelas yang sebelumnya tersembunyi. ${ }^{2}$ Jadi, dengan data mining kita dapat menemukan arti tersembunyi yang selama ini terpendam dalam basis data sepanjang dilakukan pengolahan (mining) atas data tersebut.

\subsubsection{Manfaat Data Mining}

Data mining digunakan dalam berbagai bidang seperti bisnis, pendidikan dan akademis, pemerintahan, kesehatan dan kedokteran, ekonomi, pertahanan dan keamanan, riset dan penelitian, dan banyak lagi. Manfaat lain dari penggunaan teknik data mining misalnya untuk mendeteksi kejanggalan (anomali). Pudjo (2013) menguraikan manfaat data mining dalam berbagai bidang seperti mendeteksi kejadian-kejadian ganjil penyakit tertentu dalam bidang kedokteran, mendeteksi panggilan telepon dari pihak yang berniat melakukan penipuan kartu kredit. Pada pasar swalayan, data mining dapat dimanfaatkan dalam hal pengaturan tata letak produk-produk sesuai dengan jenis dan karakteristiknya. ${ }^{3}$ Teknik data mining juga dapat digunakan pada penelitian di sektor pemerintahan. Demikian juga penelitian ini menggunakan teknik data mining pada sektor pemerintah untuk meneliti karakteristik satuan kerja terkait selisih rekonsiliasi.

1 O Folorunso, "Data Mining As A Technique For Knowledge In Business Process Redesign". Proquest Health Management: Information Management \& Computer Security, (2005).

2 Pudjo, Prabowo Widodo, Rahmadya Trias Handayatno, \& Herlawati, Penerapan Data Mining Dengan Matlab (Bandung: Rekaya Sains, 2013), hlm. 2.

3 Ibid., hlm. 3. 
Baker (2010) menyatakan bahwa manfaat data mining, bila dibandingkan dengan paradigma penelitian akademis tradisional, adalah dapat mengurangi waktu penelitian sepanjang terdapat basis data yang baik, sementara penelitian tradisional akan menghabiskan banyak waktu karena harus menghimpun data dari gudang penyimpanan. ${ }^{4}$ Baker menyatakan bahwa data mining dapat mengolah data dengan waktu yang cepat dan keberhasilan proses penelitian memberikan manfaat besar karena teknik data mining sangat memudahkan replikasi penelitianpenelitian selanjutnya. Dengan demikian dapat disimpulkan bahwa teknik data mining efektif digunakan dalam penelitian dengan data yang sangat besar. Objek dalam penelitian ini berasal dari jumlah data yang besar yaitu data rekonsiliasi seluruh KPPN konvensional pada Kanwil Provinsi Ditjen Perbendaharaan Provinsi Jakarta.

\subsubsection{Metode Data Mining dalam Penyelesaian Permasalahan}

Pudjo (2013) menyatakan bahwa dalam menyelesaikan permasalahan dengan menggunakan teknik data mining, ada dua jenis metode yang dikenal secara umum, yaitu:

a. Metode Prediksi, yaitu metode untuk memprediksikan nilai di masa yang akan datang berdasarkan variabel-variabel dalam data. Contoh metode ini adalah klasifikasi, regresi, deteksi anomali, dan lain-lain.

b. Metode Deskriptif, metode ini bermaksud membantu peneliti untuk melihat pola-pola yang berasal dari data yang ada. ${ }^{5}$

\subsubsection{Metode Klasifikasi Data Mining}

Terdapat beberapa metode data mining yang penggunaannya disesuaikan dengan tujuan penelitian dan jenis data penelitian. Beberapa metode dalam data mining yaitu klasifikasi, clustering, asosiasi, deteksi anomali, dan metodemetode lainnya. Pudjo (2013) menyatakan bahwa metode klasifikasi telah diaplikasikan pada bidang hortikultural untuk jenis tanaman tertentu. Hal ini telah dilakukan oleh Carolus van Linne yang menjadi orang pertama yang kali membuat klasifikasi jenis-jenis (spesies) tanaman ke dalam klasifikasi tertentu berdasarkan karakteristik fisik. Penelitian ini akan menggunakan metode klasifikasi untuk menemukan karakteristik satuan kerja terkait selisih hasil rekonsiliasi data keuangan.

4 Ryan S.J.D. Baker, Data Mining for Education, (Pennsylvania: Carnegie Mellon University, 2010).

5 Pudjo, et al., Op.Cit., hlm. 5.
Pola-pola atau hubungan ditemukan dari variabel-variabel seluruh anggota (instance) dalam sekumpulan data yang besar. Variabel-variabel ini sering disebut juga dengan atribut. Sekumpulan variabel dari suatu anggota data disebut record atau instance. Sementara itu data lengkap yang siap diaplikasikan dalam data mining disebut sebagai dataset sebagaimana dinyatakan Bramer (2007). ${ }^{6}$ Kelas menurut Pudjo (2013) adalah variabel/ atribut dependen yang menjadi label hasil kualifikasi misal loyalitas pelanggan (loyal atau tidak loyal), kinerja karyawan (baik, sedang, kurang), dan lain-lain. ${ }^{7}$

Ada beberapa model yang umum untuk mengklasifikasikan data. Gorunescu (2011) menguraikan model/ metode tersebut antara lain Pohon Keputusan (Decision Tree), Pengklasifikasi Bayes (Naïve Bayes Classifiers), Neural Network, KNearest Neighbour Classifier, Support Vector Machines, dan model-model lainnya. ${ }^{8}$

\subsubsection{Klasifikasi dengan Pohon Keputusan (Decision Tree)}

Metode klasifikasi yang cukup terkenal adalah metode klasifikasi decision tree (pohon keputusan). Rokach (2005) menyatakan bahwa pohon keputusan meliputi cabang-cabang yang disebut root. ${ }^{9}$ Sebuah cabang yang keluar disebut sebuah internal atau cabang uji. Lebih jauh, Rokach (2005) menyatakan bahwa setiap cabang internal terbagi menjadi dua atau lebih fungsi dari nilai atribut. Dalam bentuk dan kasus yang paling sederhana, tiap pengujian mempertimbangkan setiap atribut dan dalam hal atribut berupa angka, maka kondisi mengacu pada range.

Pudjo (2013) menyatakan bahwa terdapat empat komponen utama dalam proses klasifikasi, yaitu kelas, prediktor, set data pelatihan, dan set data uji. ${ }^{10}$ Kelas sebagai atribut merupakan variabel tidak bebas yang menjadi label kelas dalam proses klasifikasi. Beberapa contoh label kelas yaitu mahasiswa berprestasi, satker dengan penyerapan tinggi, maskapai penerbangan murah dan aman, dan lain-lain. Prediktor adalah atribut dalam dataset yang merupakan variabel bebas

6 Max Bramer, Principles of Data Mining, (Portsmouth: University of Portsmouth, 2007).

7 Pudjo, et al., Op.Cit., hlm. 5.

8 Florin Gorunescu, Data Mining: Concepts, Models, and Techniques, (Berlin: Springer, 2011).

9 Lior Rokach dan 0 Maimon, Data Mining and Knowledge Discovery Handbook. (Tel Aviv: Tel Aviv University, 2005).

10 Pudjo, et al., Op.Cit., hlm. 5. 
suatu model berdasarkan jenis dan karakteristik data. Set data pelatihan (dataset) adalah sekumpulan data yang dilengkapi dengan atributatribut tertentu yang terdiri dari kelas dan prediktor untuk menjadi data latih atas modelmodel yang dibangun. Sedangkan set data uji adalah dataset baru yang terdiri dari atributatribut yang sama dengan atribut pada set data pelatihan kecuali untuk atribut kelas.

Penelitian ini akan menggunakan teknik pengklasifikasian dengan pohon keputusan. Teknik data mining dengan menggunakan pendekatan pohon keputusan sangat efektif digunakan dalam menemukan pola, mencari arti, dan menemukan informasi yang terpendam dari kumpulan datadata. Pudjo menyatakan teknik data mining dengan pohon keputusan (decision tree) dapat menyelesaikan kasus-kasus secara sederhana dari data dalam jumlah yang sangat besar di berbagai bidang seperti kesehatan dan pengobatan, finansial, produksi, astronomi, hingga biologi molekuler. ${ }^{11}$

Lebih jauh dinyatakan bahwa klasifikasi dengan decision tree merupakan teknik yang sangat efisien dengan menyaring sesuatu lewat pohon keputusan, apakah lolos atau tidak, sehingga dapat menjelaskan dan menyelesaikan kasus dengan tingkat akurasi yang baik sepanjang data-data yang digunakan merupakan data-data yang akurat. Gorunescu (2011) menyatakan bahwa teknik data mining dengan pohon keputusan tidak digunakan bersamaan dengan teknik tradisional lainnya terutama apabila asumsi terkait distribusi datanya diuji. ${ }^{12}$ Meskipun demikian, dikatakan bahwa teknik pohon keputusan dapat berhasil dengan baik terutama saat metode penelitian tradisional tidak dapat digunakan, sehingga lebih dipilih daripada model klasifikasi lainnya.

Metode klasifikasi dengan pohon keputusan dapat dilakukan dengan berbagai algoritma. Penelitian ini akan menggunakan algoritma C4.5 untuk mengklasifikasikan karakteristik satuan kerja terkait selisih data keuangan hasil rekonsiliasi. Kotsiantis (2007) mengutip Quinlan (1993) menyatakan bahwa algoritma yang paling umum adalah algoritma C4.5. ${ }^{13}$ Beberapa peneliti memilih menggunakan klasifikasi dengan algoritma C4.5 daripada beberapa algoritma lain. Kotsiantis (2007) menyatakan bahwa hasil penelitian Tjen-Sien et al. (2000) menunjukkan bahwa algoritma C4.5 memiliki kombinasi tingkat

11 Pudjo, et al., Op.Cit., hlm. 21.

12 Florin Gorunescu, Op.Cit., hlm. 159.

13 S. B. Kotsiantis, Supervised Machine Leraning: A Review of Classification Techniques, (Tripoli: University of Peloponnese, 2007). kesalahan dan kecepatan pemprosesan yang baik. ${ }^{14}$

\subsubsection{Pemangkasan/ Pruning Pohon Keputusan (Decision Tree)}

Dataset dari sejumlah data yang sangat besar dan atribut yang sangat banyak cenderung menghasilkan pohon keputusan dalam ukuran besar dan jumlah daun yang banyak. Gorunescu (2011) menyatakan ada dua kemungkinan yang terjadi saat pohon keputusan telah terbentuk. Pertama, fenomena overfitting di mana pengujian berbagai dataset terhadap pohon keputusan menghasilkan hasil yang terlalu sama/ mirip dengan dataset awal yang digunakan dalam menguji pohon keputusan awal. Kedua, fenomena underfitting yaitu fenomena dimana kesalahan dataset latih dan pengujian sangat besar dan tidak dapat diterima. Terhadap fenomena overfitting dilakukan trimming yaitu proses pemangkasan (pruning) agar pohon tidak terlalu bercabang luas namun memiliki skala dan kecepatan pengklasifikasian yang baik. ${ }^{15}$

Ada dua tipe pruning dalam pohon keputusan menurut Gorunescu (2011), yaitu: ${ }^{16}$

1. Prepruning: yaitu pemangkasan pohon pada saat proses induksi. Kondisi utama dalam menghentikan pertumbuhan pohon adalah bahwa semua objek berada pada kelas yang sama atau semua nilai atribut sama.

2. Postpruning: yaitu pemangkasan pada saat pertumbuhan pohon telah selesai. Tangkai (node) akan dipangkas dengan memotong cabangnya. Tujuannya adalah untuk mengurangi kesalahan pengklasifikasian.

Pada penelitian ini akan dibangun modelmodel klasifikasi dengan pohon keputusan. Beberapa model dibangun dengan metode pemangkasan prepruning (onlinepruning), beberapa model dibangun dengan metode postpruning, dan satu model dibangun dengan tanpa melakukan pemangkasan (pruning) sama sekali.

\subsubsection{Langkah-Langkah Data Mining}

Ada beberapa teori yang menjelaskan pendekatan-pendekatan tertentu dalam menentukan langkah-langkah pelaksanaan pengolahan data menggunakan teknik data mining. Penelitian ini akan menggunakan model pendekatan CRISP-DM (cross industry standard process for data mining). Pendekatan CRISP-DM memberikan hasil yang lebih baik dan memberikan

\footnotetext{
14 Ibid.

15 Florin Gorunescu, Op.Cit., hlm. 180.

16 Florin Gorunescu, Op.Cit., hlm. 181.
} 
best practice bagi organisasi. Tahapan dalam CRISP-DM terbagi dalam enam tahapan sebagaimana diuraikan Shearer (2000), yaitu: ${ }^{17}$

a. Business Understanding, yaitu pemahaman tujuan-tujuan dan proses bisnis perusahaan dengan baik sehingga dapat mendefinisikan permasalahan data mining.

b. Data Understanding, dalam tahapan ini dimulai dengan pengumpulan data, menganilisisnya, mengelompokkan data-data yang saling berhubungan, dan mengidentifikasi fenomenafenomena data terkait penelitian. Ada empat tahapan dalam data understanding yaitu pengumpulan data awal, penelitian data, mengeksplorasi data, dan memverifikasi kualitas data.

c. Data Preparation, meliputi semua langkah dalam menyiapkan dataset yang akan digunakan dalam pemodelan. Aktivitasaktivitas tersebut meliputi pemilihan tabel, record, atribut, dan pembersihan (cleansing) data untuk dimodelkan. Tahapan-tahapannya meliputi persiapan, pemilihan, pembersihan (cleansing), pembangunan (konstruk), integrasi, dan transformasi data (data formatting).

d. Modeling, adalah membangun model-model dengan menggunakan algoritma yang dipilih berdasarkan relevansi dengan tujuan dan data penelitian.

e. Evaluation, model-model tertentu dievaluasi sebelum diputuskan untuk dipilih. Evaluasi penting untuk menentukan bahwa pembangunan model sesuai dengan tujuan yang ingin dicapai dalam data mining. Evaluasi model-model yang ada menggunakan beberapa alat pengukuran akurasi. Evaluasi model-model dalam penelitian ini dilakukan berdasarkan beberapa alat pengukuran hasil klasifikasi yaitu tingkat correctly classified rate True Positive Rate (TP), Area Under Curve ROC (AUC), dan Kappa Statistic. Tingkat correctly classified menunjukkan seberapa besar keberhasilan data dalam mengklasifikasikan instances secara tepat ke dalam tiap-tiap kelasnya. TP rate dapat diartikan sebagai akurasi ketepatan model dalam mengklasifikasikan instance dalam satu kelas. Kappa statistic menunjukkan konsistensi model dalam pengklasifikasian. Nilai kappa statistic berada pada rentang 0 sampai dengan 1 di mana nilai 0 berarti tidak terbentuk klasifikasi dari model dan nilai mendekati 1

17 Colin Shearer, Journal of Data Mining, (North Hollywood: The Data Warehousing Institute, 2000). menunjukkan bahwa model berhasil dengan baik melakukan klasifikasi. Azis (2015) mengacu pada Vierra dan Joanne (2008) mengungkapkan bahwa nilai kappa statistic dapat diinterpretasikan ke dalam 6 kategori yang diuraikan dalam tabel $1 .^{18}$

Tabel 1. Interpretasi Kappa Statistic

\begin{tabular}{|c|l|}
\hline Nilai & \multicolumn{1}{|c|}{ Interpretasi } \\
\hline$<0$ & Less than chance agrrement \\
\hline $0,01-0,20$ & Slight Agreement \\
\hline $0,21-0,40$ & Fair Agreement \\
\hline $\mathbf{0 , 4 1}-0,60$ & Moderate Agreement \\
\hline $\mathbf{0 , 6 1}-0,80$ & Substantial Agreement \\
\hline $\mathbf{0 , 8 1}-0,99$ & Almost Perfect Agreement \\
\hline
\end{tabular}

Sumber: Vierra dan Joanne (2008).

Nilai AUC menunjukkan nilai berdasarkan kurva Receiver Operating Character (ROC) yang menunjukkan apabila area mendekati ke kiri kurva maka klasifikasi kurang berhasil, sebaliknya semakin ke kanan maka TP rate semakin besar yang menunjukkan bahwa klasifikasi semakin baik (Gorunescu, 2011). Nilai $A U C$ berada pada rentang nilai 0 sampai dengan 1. Gorunescu (2011) membuat lima kategori terhadap nilai AUC yang diuraikan dalam tabel 2 .

Tabel 2. Nilai $A U C$

\begin{tabular}{|c|c|}
\hline Nilai & Kategori (Classification) \\
\hline $0,9-1$ & Excellent \\
\hline $0,8-0,9$ & Good \\
\hline $0,7-0,8$ & Fair \\
\hline $0,6-0,7$ & Poor \\
\hline $0,5-0,6$ & Failure \\
\hline
\end{tabular}

Sumber: Gorunescu (2011).

f. Penerapan (Deployment), tahapan terakhir adalah pengaplikasian model. Dalam tahap deployment ini diyakini bahwa model akan berkerja dengan baik bagi organisasi pengguna.

18 Saeful Azis, Karakterisasi Satuan Kerja Terkait Inakurasi Perencanaan Kas Dengan Menggunakan Teknik Data Mining (Studi Kasus Satuan Kerja Lingkup Kanwil DJPBN Provinsi Bengkulu), (Tangerang Selatan: PKN STAN, 2015). 


\section{METODOLOGI PENELITIAN}

\subsection{Kebijakan dan Tata Cara Rekonsiliasi}

Pelaksanaan rekonsiliasi data-data keuangan yang dilakukan antara KPPN selaku Kuasa Bendahara Umum Negara dengan satker dilaksanakan mengacu pada ketentuan yang mengatur tata cara pelaksanaan rekonsiliasi. Mengacu pada modul mengenai rekonsiliasi dalam rangka penyusunan laporan keuangan dinyatakan bahwa kunci penting dalam penyusunan laporan keuangan pemerintah adalah pada proses rekonsiliasi data keuangan. Laporan keuangan yang telah direkonsiliasi memberikan nilai keterandalan pada karakteristik kualitatif dalam laporan keuangan sehingga pembaca laporan keuangan tidak memperoleh informasi yang bias.

Penyusunan laporan keuangan kementerian lembaga dilakukan secara berjenjang sesuai dengan kewenangan yang diwujudkan dalam unitunit akuntansi. Jenjang unit akuntansi dalam kementerian/ lembaga secara berjenjang yaitu:

a. Unit Akuntansi Kuasa Pengguna Anggaran (UAKPA) yang secara kedudukan umumnya berada pada eselon 4 dan eselon 3 dalam suatu kementerian/ lembaga.

b. Unit Akuntansi Pembantu Pengguna AnggaranWilayah (UAPPA-W) umumnya melekat pada kantor-kantor wilayah kementerian/ lembaga setingkat eselon 2 .

c. Unit Akuntansi Pembantu Pengguna AnggaranEselon 1 (UAPPA-E1) merupakan unit akuntansi yang dilakukan oleh jenjang eselon 1 dalam kementerian/ lembaga.

d. Unit Akuntansi Pengguna Anggaran (UAPA). Unit akuntansi yang dilaksanakan oleh kementerian/ lembaga.

Tiap-tiap unit akuntansi tersebut di atas melakukan proses akuntansi dan menyusun laporan keuangan secara berjenjang. UAKPA melakukan pemrosesan data transaksi APBN melalui Sistem Akuntansi Instansi. Secara singkat, gambaran umum proses penyusunun laporan keuangan kementerian secara berjenjang diuraikan sebagai berikut:

a. Laporan Keuangan Kementerian Lembaga (LKKL) yang disusun oleh UAKPA.

b. Laporan dimaksud disampaikan secara berkala kepada UAPPA-W. Laporan tersebut paling tidak mencakup laporan realisasi anggaran (LRA), Neraca, dan Catatan atas Laporan Keuangan (CaLK).

c. UAPPA-W kemudian mengonsolidasikan seluruh LKKL dari beberapa UAKPA yang secara kedudukan berada di bawah suatu
UAPPA-W. UAPPA-W dari berbagai wilayah provinsi kemudian menyampaikan LRA, Neraca, dan CaLK konsolidasian tingkat wilayah kepada UAPPA-E1.

d. UAPPA-E1 mengonsolidasikan laporan-laporan konsolidasian tingkat wilayah provinsi untuk menyusun laporan keuangan kementerian/ lembaga tingkat eselon 1. Laporan keuangan tersebut antara lain meliputi LRA tingkat eselon 1, Neraca tingkat eselon 1, dan CaLK tingkat eselon 1.

Menteri dan pimpinan lembaga menyusun Laporan Keuangan Kementerian Lembaga (LKKL) yaitu konsolidasian atas seluruh laporan keuangan yang disusun oleh UAKPA, UAPPA-W, UAPPA-E1 secara berjenjang. Laporan keuangan tersebut terdiri dari LRA, Neraca, dan CaLK tingkat kementerian/ lembaga.

Dalam lingkup Bendahara Umum Negara, Sistem Akuntansi Pusat (SiAP) dilaksanakan oleh unit-unit yang berada pada lingkup Ditjen Perbendaharaan. Rangkaian proses penyusunan laporan keuangan pemerintah pusat (LKPP) diuraikan menjadi:

a. KPPN selaku UAKBUN Daerah melakukan penyusunan LKPP tingkat BUN Daerah atas seluruh transaksi APBN seluruh satuan kerja yang masuk dalam wilayah kerja.

b. KPPN menyampaikan LKPP tingkat BUN Daerah kepada Kantor Wilayah Ditjen Perbendaharaan. Kanwil Ditjen Perbendaharaan kemudian melakukan konsolidasian atas seluruh LKPP tingkat kuasa BUN Daerah.

c. Kantor Wilayah Ditjen Perbendaharaan menyampaikan konsolidasian LKPP tingkat wilayah kepada eselon 1 untuk dilakukan penyusunan LKPP tingkat eselon 1.

d. LKPP disusun sebagai konsolidasian secara berjenjang atas seluruh LKPP mulai tingkat kuasa BUN Daerah.

Penyusunan LKKL dan LKPP sebagaimana diuraikan di atas secara jelas menunjukkan bahwa pencatatan akuntansi atas transaksi APBN oleh BUN dan kementerian lembaga melalui sistem akuntansi yang berbeda. Oleh karena itu, sebagaimana diamanatkan oleh undang-undang, BUN dan kementerian/ lembaga terlebih dahulu melakukan rekonsiliasi keuangan untuk mendeteksi kesalahan pencatatan transaksi. Rekonsiliasi dilakukan secara berjenjang sesuai dengan kewenangan dan unit akuntansi yang dimulai pada tingkat KPPN dan satker.

Untuk mewujudkan pelaksanaan rekonsiliasi
yang efektif disusun kebijakan-kebijakan 
rekonsiliasi sebagaimana diatur dalam Peraturan Menteri Keuangan Nomor 210 Tahun 2013. Beberapa hal penting terkait kebijakan dalam rekonsiliasi lingkup kementerian/ lembaga adalah sebagai berikut:

a. Satuan kerja di daerah yang merupakan bagian dari kewenangan Kantor Pusat (KP), yang merupakan satker instansi wilayah, tetap menggunakan kode wilayah sesuai DIPA. Satuan kerja dimaksud melakukan rekonsiliasi dengan KPPN mitra dan menyampaikan laporan keuangan kepada UAPPA-W, UAPPAW selanjutnya melakukan rekonsiliasi dengan Kantor Wilayah Ditjen Perbendaharaan dan mengirimkan hasilnya ke UAPPA-E1.

b. Satuan kerja perangkat daerah (SKPD) yang menerima dana dekonstransi/ tugas pembantuan (DK/TP) dari kementerian/ lembaga yang tidak memiliki kantor vertikal di provinsi/ kab/ kota, dan hanya ada satu satuan kerja per eselon 1, maka tidak perlu melakukan rekonsiliasi tingkat wilayah, tetapi menyampaikan laporan keuangan dengan melampirkan Salinan BAR bulan terakhir dari KPPN setiap triwulan dan mengirimkan laporan keuangan langsung kepada eselon 1 K/L.

c. Bagian Anggaran yang memiliki beberapa kantor vertikal di daerah dengan jenis kewenangan KD, tetapi tidak mempunyai kantor wilayah harus menunjuk salah satu satuan kerja sebagai UAPPA-W.

d. Untuk K/L yang tidak memiliki kantor wilayah dalam struktur organisasinya, namun memiliki satuan kerja (baik Dekonsentrasi, TP, KD, UPT, SNVT) di wilayahnya yang mendapatkan dana dari beberapa eselon 1 yang berbeda, harus membuat UAPPA-W. UAPPA-W tersebut adalah salah satu dari satuan kerja (baik Dekonsentrasi, TP, KD, UPT, SNVT) tersebut. UAPPA-W tersebut dapat dibentuk per eselon 1 atau per wilayah.

e. Rekonsiliasi satuan kerja dan UAPPA-W dengan KPPN dan Kanwil DJPB yang lokasinya tidak sama dilakukan sebagai berikut:

1. Satker tersebut wajib melakukan rekonsiliasi dengan KPPN mitra kerja, namun UAPPA-W tidak wajib melakukan rekonsiliasi dengan Kantor Wilayah DJPB yang membawahi KPPN tersebut;

2. KPPN mitra kerja satker tersebut wajib mengirimkan BAR dan LHR ke Kanwil DJPBN mitra kerja UAPPA-W yang membawahi satker tersebut;

3. Satker tersebut wajib mengirimkan data UAPPA-W, selanjutnya UAPPA-W melakukan rekonsiliasi dengan Kanwil DJPB mitra kerjanya;

4. Kanwil DJPB mencocokkan perbedaan dan hasil rekonsiliasi dengan BAR dan Laporan Hasil Rekonsiliasi (LHR) yang dikirimkan oleh KPPN;

5. Satuan kerja yang melakukan pencairan dana/ pengesahannya di beberapa KPPN wajib melakukan rekonsiliasi dengan beberapa KPPN di mana satker tersebut melakukan pencairan dananya;

6. Bagian Anggaran (BA/Eselon 1) yang mempunyai beberapa UAPPA-W dalam satu wilayah maka setiap UAPPA-W harus melakukan rekonsiliasi dengan Kanwil DJPBN berdasarkan satuan kerja di wilayahnya.

Kantor Pelayanan Perbendaharaan Negara (KPPN) selaku Kuasa BUN Daerah melaksanakan rekonsiliasi dengan satuan kerja. Rekonsiliasi pada tingkat Kuasa BUN Daerah antara KPPN dan satuan kerjanya merupakan titik paling penting dalam proses rekonsiliasi dan penyusunan laporan keuangan karena dalam jenjang ini proses input data transaksi APBN dilakukan sementara pada jenjang-jenjang di atasnya hanya sebatas konsolidasian saja. Beberapa poin-poin penting terkait pelaksanaan rekonsiliasi tingkat kuasa BUN daerah antara lain:

a. KPPN selaku UAKBUN-D melakukan rekonsiliasi laporan realisasi anggaran;

b. Neraca SAU beserta data transaksi dengan seluruh satuan kerja di wilayahnya setiap bulan. KPPN mengirim ADK dan laporan kepada Kanwil Ditjen Perbendaharaan;

c. Untuk estimasi pendapatan yang terdapat dalam SAU, KPPN melakukan penginputan estimasi pendapatan sesuai dengan DIPA satker mitra kerjanya;

d. Kanwil Ditjen Perbendaharaan selaku UAKBUN-Kanwil melakukan rekonsiliasi dengan UAPPA-W di wilayah kerjanya setiap triwulanan. Kanwil Ditjen Perbendaharaan mengirimkan ADK dan laporan kepada Direktorat Akuntansi dan Pelaporan Keuangan (APK) dan Direktorat Pengelolaan Kas Negara (PKN);

e. Dit. PKN dan selaku UAKBUN-P melakukan rekonsiliasi Laporan Realisasi Anggaran dan Neraca SAU beserta data transaksi dengan seluruh satuan kerja yang memiliki pendapatan, penerimaan pembiayaan dan pengeluaran pembiayaan melalui rekening yang dikuasai Dit. PKN; 
f. Setiap penerbitan Berita Acara Rekonsiliasi (BAR) harus dilampiri dengan Laporan Hasil Rekonsiliasi (LHR).

\subsection{Masalah Yang Dihadapi}

Pelaksanaan rekonsiliasi merupakan langkah yang harus dilakukan oleh Bendahara Umum Negara sebelum menyusun Laporan Keuangan Pemerintah Pusat. Kualitas informasi yang disajikan dalam laporan keuangan sangat tergantung pada efektivitas proses rekonsiliasi. Rekonsiliasi yang efektif adalah rekonsiliasi yang dapat mendeteksi adanya kesalahan (selisih) dalam pencatatan transaksi baik oleh KPPN maupun oleh satuan kerja. Fungsi check and balance ini menjadi alat deteksi kesalahan sehingga tindakan koreksi dapat dilakukan terkait pencatatan.

Pemerintah selaku pengguna sumber daya keuangan dalam menyelenggarakan keuangan diwajibkan untuk melakukan penyusunan laporan keuangan pemerintah pusat sebagai bentuk pertanggungjawaban dan akuntabilitas dalam pelaksanaan anggaran. Hal ini sesuai dengan amanat Undang-Undang Nomor 17 tahun 2003 (pasal 8) dan Undang-Undang Nomor 1 Tahun 2004 (pasal 51).

LKPP yang disusun oleh Menteri Keuangan c.q. Ditjen Perbendaharan atas seluruh transaksi APBN dalam satu periode tahun anggaran disampaikan kepada kepada Presiden sebagai wujud pertanggungjawaban dan Badan Pemeriksa Keuangan untuk dilakukan pemeriksaan. Hasil audit atas penyusunan Laporan Keuangan Pemerintah Pusat (LKPP) untuk dua tahun terakhir adalah pemberian opini Wajar Dengan Pengecualian (WDP) untuk LKPP tahun 2013 dan 2014.

Sebagaimana diuraikan dalam bagian pendahuluan penelitian ini, temuan BPK terkait atas audit LKPP adalah adanya selisih pencatatan antara SAU dan SAI yang merupakan bagian dari proses rekonsiliasi. Dalam laporan audit BPK atas LKPP tahun 2013 disebutkan bahwa perbedaan pencatatan belanja antara SAU dan SAI sebesar Rp140.397.661.708,- (neto) atau secara absolut sebesar Rp272.905.428.156,-. Diungkapkan lebih lanjut, pemerintah belum menindaklanjuti data berbeda sejak tahun 2004 sampai dengan 2012 . Dalam laporan hasil pemeriksaan (audit) atas LKPP 2014, BPK mengungkapkan temuan bahwa proses rekonsiliasi antara BUN dan K/L tidak efektif sehingga masih ada perbedaan data di mana K/L mencatat belanja lebih besar senilai Rp557,36 miliar.

Permasalahan selisih atas rekonsiliasi KPPN (BUN) dan satuan kerja (K/L) merupakan permasalahan yang terjadi sepanjang tahun. KPPN selaku unit vertikal Ditjen Perbendaharaan mengemban fungsi melakukan bimbingan teknis dan supervisi di bidang akuntansi dan pelaporan keuangan dan fungsi dalam melakukan pemantauan dan evaluasi di bidang akuntansi dan pelaporan.

\subsection{Alternatif Pemecahan Masalah}

Dalam usaha mewujudkan penyusunan LKPP yang andal tahap-tahap penyusunan harus dilaksanakan dengan mempertimbangkan nilai akurasi dan validitas data-data transaksi APBN. Untuk memastikan akurasi dan validitas tersebut, maka dilakukan rekonsiliasi mendahului penyusunan laporan keuangan. Temuan BPK atas LKPP tahun 2013 dan 2014 menyatakan bahwa adaselisih pencatatan antara BUN dengan kementerian/ lembaga. Hal ini menunjukkan bahwa dalam proses rekonsiliasi masih ditemukan selisih (perbedaan pencatatan).

Pelaksanaan bimbingan teknis, supervisi, pemantauan, monitoring, dan evaluasi terkait akuntansi dan pelaporan akan berjalan dengan efektif bila difokuskan pada satuan kerja dengan karakteristik yang rentan terhadap perbedaan hasil rekonsiliasi (beda pencatatan transaksi). Terkait upaya meminimalkan terjadinya perbedaan (selisih) karena kesalahan pencatatan, maka dalam pelaksanaan fungsi supervisi, bimbingan teknis, dan monitoring evaluasi tersebut, perlu diidentifikasi faktor-faktor yang mempengaruhi proses rekonsiliasi. Hal ini dilakukan agar satuan-satuan kerja dengan karakteristik yang rentan dengan kesalahan pencatatan dapat lebih fokus dalam menerima bimbingan teknis dan supervisi oleh KPPN.

Penggunaan teknik data mining dapat digunakan untuk melihat pola-pola tersembunyi yang menjelaskan hubungan keterkaitan data-data dalam suatu basis data yang sangat besar. Penggunaan teknik data mining dapat dilakukan untuk mengidentifikasi faktor-faktor yang mempengaruhi proses rekonsiliasi. Faktor-faktor yang teridentifikasi tersebut digunakan untuk mengklasifikasikan karakteristik satuan kerja yang menjadi fokus supervisi, bimbingan, monitoring, dan evaluasi. Pelaksanaan kegiatan supervisi, bimbingan, monitoring, dan evaluasi lebih intens dan fokus pada satker-satker tertentu. Hal ini diharapkan dapat mengurangi dan mencegah terjadinya perbedaan dan/ atau kesalahan pencatatan atas transaksi-transaksi APBN.

\subsection{Tahapan-Tahapan Penelitian}

Penelitan ini menggunakan teknik data mining dengan pendekatan CRISP-DM (Cross Industry Standard Proces for Data Mining). Hermawan (2015) mengutip Shearer (2000), yang menyatakan CRISP-DM merupakan pendekatan 
dalam data mining dengan tahapan-tahapan teknis meliputi pemahaman data (data understanding), penyiapan data (data preparation), perancangan model (modeling), evaluasi, dan aplikasi/ penerapannya. ${ }^{19}$

\section{a. Business Understanding}

Pemahaman proses bisnis (business understanding) adalah pemahaman tujuantujuan dan proses bisnis perusahaan dengan baik sehingga dapat mendefinisikan permasalahan data mining.

b. Pemahaman Data

Tahapan pertama dalam penelitian ini akan dimulai dengan memahami data-data yang terkait dengan penelitian. Pemahaman akan data sangat penting dalam penelitian terutama dengan menggunakan teknik data mining. Data-data yang terkait dengan penelitan meliputi data-data realisasi anggaran, data DIPA satuan kerja, daftar hasil rekonsiliasi, data daftar Surat Perintah Pencairan Dana (SP2D), daftar revisi DIPA, dan data-data lain yang terkait dengan penelitian.

c. Penyiapan Data

Hermawan (2015) menyatakan bahwa tahapan penyiapan data merupakan proses yang meliputi pemilihan data, pembersihan data, konstruksi data, dan integrasi data. ${ }^{20}$ Data yang digunakan dalam penelitian ini adalah data yang diperoleh dari Kantor Pusat Ditjen Perbendaharaan.

d. Perancangan Model

Perancangan model merupakan tahapan ketiga dalam teknik data mining dengan pendekatan CRISP. Pemodelan akan dilakukan dengan menggunakan klasifikasi pohon keputusan (decision tree). Teknik ini dipilih karena mampu membangun model dengan tingkat akurasi yang tinggi sepanjang data yang digunakan memiliki akurasi yang baik. Teknik klasifikasi pohon keputusan membantu memahami hubungan-hubungan antardata dari suatu proses sehingga relevan dengan permasalahan dan pencapaian tujuan penelitian. Pembangunan model akan menggunakan aplikasi WEKA versi 3.6.13 dengan menggunakan parameter-parameter yang ada pada aplikasi tersebut.

19 Randy Hermawan, Penggunaan Teknik Data Mining untuk Memprediksi Kondisi Financial Distress pada Pemerintah Daerah Kabupaten/ Kota di Indonesia, Tangerang Selatan: PKNSTAN, 2015.

20 Ibid., hlm. 33.
Model hasil rancangan dievaluasi polanya untuk kemudian diidentifikasi faktor-faktor yang menjadi tujuan penelitian. Dari berbagai model yang berhasil dirancang dipilih model dengan tingkat akurasi yang paling baik.

e. Evaluasi Model

Pada tahapan Evaluasi Model, seluruh model-model yang dibangun selanjutnya dievaluasi kinerjanya dalam melakukan klasifikasi. Evaluasi dilakukan dengan tujuan untuk mendapatkan model dengan kinerja pengklasifikasian terbaik. Beberapa aspek yang digunakan dalam tahapan evaluasi model adalah tingkat keberhasilan pengklasifikasian (correctly classified), nilai kappa statistic, nilai area under curve (AUC), serta ukuran dan besar pohon keputusan yang terbentuk.

f. Penerapan (Deployment)

Penerapan (Deployment) merupakan tahapan terakhir, yaitu pengaplikasian model. Hal pokok yang menjadi perhatian dalam tahap deployment ini adalah keyakinan bahwa model akan bekerja dengan baik bagi organisasi pengguna. Penerapan dilakukan dengan memasukkan dataset yang belum diberikan label kelas berdasarkan model yang terpilih.

\subsection{Definisi Operasional}

\subsubsection{Selisih}

Yang dimaksud dengan selisih pada penelitian ini adalah kondisi apabila terdapat perbedaan hasil rekonsiliasi antara pencatatan pada SAI oleh satuan kerja dan SAU oleh KPPN. Selisih tersebut meliputi selisih yang disebabkan oleh DIPA, estimasi pendapatan, belanja, pengembalian belanja, realisasi PNBP, pengembalian PNBP, mutasi uang persediaan, kas pada Bendahara Pengeluaran, dan kas pada BLU.

\subsubsection{OK}

Yang dimaksud dengan $\mathrm{OK}$ adalah kondisi apabila tidak terdapat perbedaan hasil rekonsiliasi atas pencatatan pada SAI oleh satuan kerja dengan pencatatan oleh KPPN pada SAU.

\section{HASIL PENELITIAN}

Penelitan ini menggunakan teknik data mining dengan pendekatan CRISP-DM (Cross Industry Standard Proces for Data Mining). Penulis menggunakan aplikasi yang dibangun oleh Waikato University yaitu aplikasi WEKA untuk data mining.

\subsection{Pemahaman Proses Bisnis (Understanding of Bussiness Processes)}

Pelaksanaan rekonsiliasi dilaksanakan atas transaksi-transaksi pelaksanaan anggaran antara Kementerian/ Lembaga dengan BUN. Rekonsiliasi 
yang menjadi lingkup penelitian ini adalah rekonsiliasi tingkat UAKPA yaitu satker dalam suatu Kementerian/ Lembaga dengan KPPN Rekonsiliasi di tingkat UAKPA dilaksanakan setiap bulan sepanjang tahun anggaran. Sebagaimana diatur pada PMK Nomor 210/PMK.05/2013 rekonsiliasi dilaksanakan paling lambat setiap tanggal 10 bulan berikutnya atau hari kerja berikutnya bila hari tersebut libur.

Pelaksanaan rekonsiliasi tingkat UAKBUN Daerah diawali dengan satuan kerja merekam seluruh transaksi yang terjadi sepanjang bulan periode rekonsiliasi melalui aplikasi SAIBA berdasarkan dokumen-dokumen sumber. Data hasil perekaman dari aplikasi SAIBA disampaikan melalui arsip data komputer (ADK) ke KPPN untuk direkonsiliasi baik secara langsung maupun melalui sarana surat elektronik. Pada KPPN, seluruh proses transaksi direkam dan disimpan dalam satu database terpusat, yaitu database SPAN. Petugas KPPN melakukan unggah ADK satker untuk direkonsiliasi dengan data pencatatan BUN yang tersimpan dalam database SPAN. Rekonsiliasi tingkat UAK-BUN Daerah dilakukan atas transaksi DIPA, estimasi pendapatan, belanja, pengembalian belanja, pendapatan, pengembalian pendapatan, mutasi uang persediaan, kas di bendahara pengeluaran, kas di kementerian/ lembaga, dan kas pada Badan Layanan Umum.

\subsection{Pemahaman Data (Data Understanding)}

Data yang digunakan dalam penelitian ini terdiri dari beberapa kelompok data antara lain data hasil rekonsiliasi, data transaksi Surat Perintah Pencairan Dana (SP2D), dan data revisi DIPA pada tujuh KPPN kovensional dalam Kantor Wilayah Ditjen Perbendaharaan Provinsi DKI Jakarta yang menjadi objek penelitian. Data-data tersebut diperoleh dari Direktorat Sistem Informasi dan Transformasi Perbendaharaan Ditjen Perbendaharaan yang mengelola database Sistem Perbendaharaan dan Anggaran Negara (SPAN). Data mentah terkait penelitian ini diterima dalam format ekstensi excel sehingga mendukung kemudahan pengolahan dalam tahap persiapan data. Data hasil rekonsiliasi merupakan data per tanggal 4 Januari 2016 (KPPN Jakarta 1, 2, 3, 4, 5, dan 6) dan per 13 Januari 2016 untuk (KPPN Jakarta 7). Sementara itu, data SP2D dan data revisi DIPA merupakan versi termutakhir per tanggal 15 Desember 2015.

Data mentah hasil rekonsiliasi dengan satuan kerja pada tujuh KPPN yang menjadi objek penelitian tersebut terdiri dari 238.890 baris dalam ekstensi file excel. Data tersebut merupakan kompilasi seluruh satker dalam lingkup KPPN yang menjadi objek penelitian. Data-data terdiri dari atribut tiap-tiap satker, transaksi-transaksi yang direkonsiliasi, periode rekonsiliasi, dan status rekonsiliasi (OK atau SELISIH). Data mentah jumlah SP2D terdiri dari daftar nomor SP2D dan atribut satker seluruh satuan kerja yang merupakan mitra kerja ketujuh KPPN tersebut sepanjang tahun 2015. Sedangkan data revisi DIPA merupakan data yang terdiri dari daftar satkersatker yang melakukan revisi DIPA sepanjang tahun anggaran 2015.

\subsection{Persiapan Data (Data Preparation)}

Persiapan data dilakukan terhadap data mentah yang belum siap untuk diolah dalam penelitian. Tahapan ini merupakan tahapan prapemrosesan data penelitian ke dalam modelmodel. Hermawan (2015) menyatakan penyiapan data terbagi menjadi lima langkah yaitu pemilihan data, pembersihan data, penyusunan data (konstruksi), integrasi data, dan transformasi data. Seluruh tahapan dalam persiapan data dilakukan dengan aplikasi Microsoft Excel.

\section{a. Pemilihan Data}

Persiapan data diawali dengan mengklasifikasikan satuan kerja berdasarkan kelas hasil rekonsiliasi ke dalam dua kelas yaitu kelas $\mathrm{OK}$ (tidak ada selisih) dan kelas SELISIH. Langkah berikutnya adalah melakukan pemisahan transaksi berdasarkan bulan-bulan periode pelaksanaan rekonsiliasi. Persiapan data dilakukan untuk memilih data-data yang relevan dengan penelitian. Lingkup penelitian ini dibatasi pada pelaksanaan rekonsiliasi periode bulan Januari sampai November 2015. Periode pelaksanaan rekonsiliasi Desember tidak dapat dimasukkan dalam lingkup penelitian karena pelaksanaannya baru akan mulai dilakukan pada bulan Januari 2016 dan diatur secara khusus dalam Perdirjen Perbendaharaan Nomor 24 Tahun 2015 tentang Pedoman Pelaksanaan Penerimaan dan Pengeluaran Negara pada Akhir Tahun Anggaran 2015. Hal tersebut menimbulkan perbedaan dengan periode-periode sebelumnya. Untuk data-data rekonsiliasi periode sebelum tahun anggaran 2015 tidak dapat dimasukkan dalam lingkup penelitian karena tidak tersedia data sebagai bahan penelitian.

\section{b. Pembersihan Data}

Data terpilih yang relevan dengan penelitian dibersihkan dari data yang tidak dapat digunakan dalam penelitian, yaitu data yang kode satkernya kosong. Pembersihan dilakukan dengan fitur filtering dan menghapus seluruh baris data (instance) kosong (blank) pada kolom kode satker, serta atribut-atribut yang tidak relevan dalam penelitian. Kolom-kolom atribut yang tidak relevan dengan tujuan penelitian seperti kode KPPN, kode bank dan atribut lain yang tidak relevan dihapus. Sedangkan atribut kode satker, kode bagian anggaran, kode unit eselon 1, dan periode rekonsiliasi dihapus dari dataset agar pohon yang 
terbentuk dari hasil pemodelan tidak terlalu besar. Data-data hasil rekonsiliasi yang telah dibersihkan dan dipisahkan berdasarkan bulan pelaksanaan rekonsiliasi disimpan dalam satu file yang dinamakan HASIL_REKON_ALL.xlsx.

Tabel 3. Daftar Atribut

\begin{tabular}{|c|l|}
\hline No & Nama Atribut \\
\hline 1 & Jenis Dekonsentrasi \\
\hline 2 & Jumlah Fungsi \\
\hline 3 & Jumlah Subfungsi \\
\hline 4 & Jumlah Program \\
\hline 5 & Jumlah Kegiatan \\
\hline 6 & Jumlah Output \\
\hline 7 & Pagu Belanja Bansos \\
\hline 8 & Pagu Belanja Barang \\
\hline 9 & Pagu Belanja Lain-Lain \\
\hline 10 & Pagu Belanja Modal \\
\hline 11 & Pagu Belanja Pegawai \\
\hline 12 & Status Pagu Blokir \\
\hline 13 & Realisasi Bansos \\
\hline 14 & Realisasi Barang \\
\hline 15 & Realisasi Lain-Lain \\
\hline 16 & Realisasi Modal \\
\hline 17 & Realisasi Modal \\
\hline 18 & Jumlah SP2D \\
\hline 19 & Jumlah Revisi DIPA \\
\hline 20 & Klasifikasi PNBP \\
\hline
\end{tabular}

Sumber: Diolah dari database pada Direktorat SITP Ditjen Perbendaharaan

Deskripsi atas atribut-atribut tersebut diuraikan sebagai berikut:

1. Jenis Dekonsentrasi

Jenis dekonsentrasi adalah jenis atribut yang menunjukkan jenis kewenangan satuan kerja. Data penelitian yang diperoleh terdiri dari lima jenis kode dekonsentrasi, yaitu Kantor Pusat (KP) sebanyak 2.591 instances, Kantor Daerah 770 instances, Dekonsentrasi 261 instances, Tugas Pembantuan 24 instances, dan 10.136 instances kode 0 untuk instances yang tidak terisi kode.

2. Jumlah Fungsi

Atribut fungsi adalah atribut yang menunjukkan jumlah fungsi yang dimiliki oleh tiap-tiap satuan kerja. Sebanyak 12.113 instances memiliki 1 fungsi, 1.432 instances memiliki 2 fungsi, dan 237 instances memiliki 3 fungsi.

\section{Subfungsi}

Atribut subfungsi adalah atribut yang menunjukkan jumlah subfungsi tiap-tiap satker sesuai dengan nomenklatur. Instances terdiri dari 5 jenis subfungsi dengan rincian 11.069 instances dengan 1 subfungsi, 2.204 instances dengan 2 subfungsi, 429 instances dengan jumlah subfungsi 3, 69 instances dengan jumlah subfungsi 4, dan 11 instances dengan 11 subfungsi.

4. Program

Atribut program adalah jumlah program yang dimiliki tiap satuan kerja sesuai dengan pelaksanaan tugas fungsinya. Dalam penelitian ini terdapat delapan jenis jumlah program yang dimiliki tiap-tiap instances. Jumlah terkecil adalah data (instance) dengan nilai 1 dan nilai jumlah program terbesar adalah 10 seperti digambarkan dalam tabel 4 .

Tabel 4. Rincian Atribut Program

\begin{tabular}{|c|c|l|}
\hline No & Jumlah Program & Instances \\
\hline 1 & 1 & 10.718 \\
\hline 2 & 2 & 2.306 \\
\hline 3 & 3 & 446 \\
\hline 4 & 4 & 153 \\
\hline 5 & 6 & 61 \\
\hline 6 & 7 & 22 \\
\hline 7 & 8 & 65 \\
\hline 8 & 10 & 11 \\
\hline
\end{tabular}

Sumber: data excel yang telah diolah

Persebaran nilai-nilai jumlah program tersebut sangat bervariasi di mana jumlah program 1 adalah yang terbanyak dengan 10.718 instances dan jumlah program paling sedikit adalah 10 dengan 11 instances. Rincian jenis program dan instances dalam data diuraikan pada tabel.

\section{Kegiatan}

Atribut kegiatan merupakan jumlah aktivitas yang akan dilaksanakan satuan kerja dalam pelaksanaan program. Atribut kode kegiatan dalam penelitian ini terdiri dari 36 jenis di mana instances (satker) dengan jumlah kegiatan di atas 8 jumlah instances-nya kurang dari 100 sementara itu satker yang jumlah kegiatannya kurang atau sama dengan 8 jumlah instances-nya lebih dari 100 . Instances dengan 1 dan 2 kegiatan paling banyak dalam data yaitu dengan jumlah instances 6.391 dan 2.788 .

6. Output

Atribut output menunjukkan banyaknya output dalam kegiatan-kegiatan dalam DIPA satuan kerja. Terdapat 39 jenis jumlah output satuan kerja (instances) dalam data. Jumlah 
program 3, 6, 7, dan 8 merupakan jumlah program yang terbanyak dalam data yaitu dengan masing-masing berjumlah di atas 1.000 instances.

\section{Pagu Belanja Bantuan Sosial (57)}

Atribut pagu belanja bantuan sosial merupakan atribut yang menunjukkan kepemilikan pagu tersebut pada tiap-tiap satker (instances). Jumlah instances yang memiliki atribut ini adalah 1.296 instances dan diberi label ADA sementara satker (instances) yang tidak memiliki sebanyak 12.486 instances dan diberi label TIDAK ADA.

8. Pagu Belanja Barang (52)

Atribut pagu belanja barang menunjukkan jumlah pagu belanja barang yang dimiliki tiap satker pada Tahun Anggaran 2015 dengan rincian pada Tabel 5. Dalam menetapkan label atribut penulis tidak menemukan literatur baku yang menetapkan dasar pelabelan atribut realisasi, pagu, realisasi belanja, dan besaran PNBP. Azis (2015) yang meneliti karakterisasi satker terkait inakurasi perencanaan kas dengan menggunakan teknik data mining menetapkan sendiri label atas atribut pagu, realisasi, jumlah kegiatan, retur SPM, dan atribut lainnya. Penelitian ini mengacu pada penelitian Azis (2015) dengan menetapkan sendiri label-label atribut pagu, realisasi anggaran, dan PNBP.

Dari tabel tersebut dapat dilihat bahwa nilai pagu belanja dengan label SEDANG dan BESAR adalah nilai label dengan instances paling besar yaitu dengan jumlah instances masing-masing 5.605 dan 5.245 sementara dengan label TIDAK ADA berjumlah paling sedikit (317).

Tabel 5. Label Belanja Barang

\begin{tabular}{|c|l|c|l|}
\hline No & $\begin{array}{c}\text { Nilai Pagu Belanja } \\
\text { Barang }\end{array}$ & \multicolumn{1}{|c|}{ Label } & \multicolumn{1}{|c|}{$\begin{array}{l}\text { Jumlah } \\
\text { Instances }\end{array}$} \\
\hline 1 & 0 & TIDAK ADA & 317 \\
\hline 2 & $<200$ juta & KECIL & 622 \\
\hline 3 & $\begin{array}{l}<200 \text { juta s.d. }<10 \\
\text { miliar }\end{array}$ & SEDANG & 5.605 \\
\hline 4 & $\begin{array}{l}<10 \text { miliar s.d. }< \\
100 \text { miliar }\end{array}$ & BESAR & 5.245 \\
\hline 5 & $>100$ miliar & $\begin{array}{c}\text { SANGAT } \\
\text { BESAR }\end{array}$ & 1.993 \\
\hline
\end{tabular}

Sumber: data excel yang telah diolah

9. Pagu Belanja Lain-Lain (58)

Atribut pagu belanja lain-lain (58) menunjukkan kepemilikan pagu belanja lainlain pada satker. Jumlah satker yang memiliki pagu belanja 58 sebanyak 22 satker (instances) dan diberi label ADA sementara instances yang tidak memiliki pagu belanja 58 sebanyak 13.760 diberi label TIDAK ADA.

\section{Pagu Belanja Modal (53)}

Atribut pagu belanja modal menunjukkan kepemilikan belanja modal pada satker. Nilai pagu belanja modal diberi label sesuai berdasarkan range pada Tabel 5 . Satker (instances) dengan pagu SEDANG sebanyak 6.541 instances, label TIDAK ADA 3.078, KECIL 1.494, BESAR, 2.665, dan SANGAT BESAR 4 instances.

11. Pagu Belanja Pegawai (51)

Atribut Belanja Pegawai (51) merupakan atribut yang menunjukkan besaran pagu belanja pegawai satker. Nilai pagu belanja pegawai diberi label berdasarkan rentang nilai sebagimana pada Tabel 5. Sebanyak 4.786 instances memiliki pagu BESAR, 5.215 instances dengan pagu 51 SEDANG, 3.297 instances berlabel TIDAK ADA, 460 instances dengan label KECIL, dan 24 instances memiliki pagu SANGAT BESAR.

12. Blokir

Satker yang memiliki pagu dengan status blokir diberi label ADA dan yang tidak diblokir diberi label TIDAK ADA. Sebanyak 61 instances diberi label ADA dan 13.721 diberi label TIDAK ADA.

13. Realisasi Belanja Bantuan Sosial (57)

Atribut ini menunjukkan jumlah realisasi belanja 57 pada tiap bulan pelaksanaan rekonsiliasi. Sebanyak 327 instances yang memiliki realisasi belanja 57 diberi label ADA dan 13.455 instances tanpa realisasi belanja 57 diberi label TIDAK ADA.

14. Realisasi Belanja Barang (52)

Atribut ini merupakan atribut realisasi belanja barang satker tiap bulan periode rekonsiliasi. Nilai realisasi dimasukkan ke dalam label-label berdasarkan besaran realisasinya sebagaimana diuraikan pada tabel berikut.

Tabel 6. Label Realisasi Belanja Barang

\begin{tabular}{|c|l|l|l|}
\hline No & \multicolumn{1}{|c|}{ Nilai Pagu Belanja Barang } & \multicolumn{1}{|c|}{ Label } & $\begin{array}{c}\text { Jumlah } \\
\text { Instances }\end{array}$ \\
\hline 1 & 0 & TIDAK ADA & 2.325 \\
\hline 2 & $<500$ juta & KECIL & 4.386 \\
\hline 3 & $<500$ juta s.d. $<10$ miliar & SEDANG & 6.036 \\
\hline 4 & $<10$ miliar s.d $<100$ miliar & BESAR & 938 \\
\hline 5 & $>100$ miliar & $\begin{array}{l}\text { SANGAT } \\
\text { BESAR }\end{array}$ & 117 \\
\hline
\end{tabular}

Sumber: data excel yang telah diolah 
Instances dengan nilai realisasi belanja barang dengan label KECIL dan label SEDANG merupakan jumlah instances terbanyak dalam dataset berturut-turut yaitu 4.386 dan 6.036 instances. Sementara label SANGAT BESAR merupakan kelompok dengan jumlah instances paling sedikit yaitu sebanyak 117 instances.

15. Realisasi Belanja Lain-Lain (58)

Atribut realisasi belanja 58 menunjukkan realisasi belanja 58 pada satker. Jumlah satker yang memiliki realisasi belanja 58 sebanyak 15 instances dan diberi label ADA. Sementara jumlah instances yang tidak memiliki realisasi belanja 58 sebanyak 13.767 instances dan diberi label TIDAK ADA.

16. Realisasi Belanja Modal (53)

Atribut ini menunjukkan besaran realisasi belanja modal yang terjadi tiap bulan (tidak akumulasi) pelaksanaan rekonsiliasi. Besaran realisasi diberi label sesuai dengan rentang nilai pada Tabel 6. Label TIDAK ADA dimiliki 8.943 instances, KECIL 3.221, label SEDANG sebanyak 1.275 instances, dan label sangat besar 77 .

17. Realisasi Belanja Pegawai (51)

Atribut ini menunjukkan besaran realisasi belanja pegawai yang terjadi tiap bulan (tidak akumulasi) pelaksanaan rekonsiliasi. Besaran realisasi diberi label sesuai dengan rentang nilai pada Tabel 6. Label TIDAK ADA dimiliki 3.782 instances, KECIL 3.681, label SEDANG sebanyak 5.754 instances, dan label sangat besar 59 .

18. SP2D

Atribut SP2D menunjukkan banyaknya SP2D yang diterbitkan untuk masing-masing satker per bulan (tidak akumulasi). Terdapat 543 variasi jumlah SP2D dalam data penelitian. Jumlah SP2D per bulan paling kecil adalah 0 (tidak terbit SP2D) dan paling besar per bulan adalah 1.194 SP2D.

19. Revisi DIPA

Atribut revisi DIPA menunjukkan jumlah revisi DIPA per periode rekonsiliasi. Jumlah revisi DIPA per bulan (tidak akumulasi) paling kecil dengan jumlah 0 (tidak ada revisi yang terbit) dan paling besar 66 .

20. Realisasi Pendapatan Negara Bukan Pajak (PNBP)

Atribut PNBP menunjukkan kepemilikan realisasi PNBP per bulan (tidak akumulasi). Nilai realisasi PNBP dimasukkan ke dalam enam label berdasarkan besaran nilai masingmasing sebagaimana diuraikan pada tabel berikut.
Tabel 7. Label Realisasi PNBP

\begin{tabular}{|c|l|l|l|}
\hline No & Nilai Realisasi PNBP & Label & $\begin{array}{l}\text { Jumlah } \\
\text { Instance }\end{array}$ \\
\hline 1 & 0 & TIDAK ADA & 10.084 \\
\hline 2 & $<1.000 .000$ & KECIL & 1.858 \\
\hline 3 & $<1000.000$ s.d. $<100$ juta & $\begin{array}{l}\text { SANGAT } \\
\text { KECIL }\end{array}$ & 686 \\
\hline 4 & $<100$ juta s.d $<1$ miliar & SEDANG & 699 \\
\hline 5 & $<1$ miliar s.d $<10$ miliar & BESAR & 318 \\
\hline 6 & $>10$ miliar & $\begin{array}{l}\text { SANGAT } \\
\text { BESAR }\end{array}$ & 137 \\
\hline
\end{tabular}

Sumber: data excel yang telah diolah

Berdasarkan tabel dapat dilihat nilai-nilai realisasi PNBP dengan label TIDAK ADA merupakan label dengan jumlah instances terbanyak yaitu 10.084 instances. Sementara nilai label terkecil adalah label SANGAT BESAR dengan jumlah 137 instances.

\section{c. Konstruksi Data}

Data-data terpilih yang telah dibersihkan selanjutnya disusun/ dibangun sesuai dengan kepemilikan seluruh atribut masing-masing satker berdasarkan bulan-bulan pelaksanaan rekonsiliasi. Namun sebelum dilakukan proses konstruksi data secara bulanan, atribut pagu, realisasi belanja, dan atribut PNBP dimasukkan ke dalam kelas-kelas.

Konstruksi data dilakukan berdasarkan data bulanan dengan cara mengisi atribut masingmasing satker berdasarkan file daftar SP2D dan file daftar revisi DIPA dengan menggunakan fungsi vlookup. Tiap baris dalam data mewakili hasil rekonsiliasi dan kondisi tiap-tiap satker dalam suatu periode bulan pelaksanaan rekonsiliasi. Hasil seluruh data yang dikonstruksi menjadi dataset bulanan disimpan ke dalam sebelas sheet bulan dalam satu file HASIL_REKON_ALL.xlsx.

\section{d. Integrasi Data}

Tahap integrasi data adalah proses menyatukan seluruh data penelitian yang telah dipilih, dibersihkan, dan disusun menjadi satu kumpulan data. Satu kumpulan ini disebut sebagai dataset yang digunakan pada proses modeling. Proses integrasi data dilakukan dengan menggabungkan seluruh instance (baris data) pada sebelas sheet bulan pelaksanaan rekonsiliasi dari file HASIL_REKON_ALL.xlsx dan menyimpan dalam satu file dataset baru yaitu file DATASET_RANGE.xlsx. Dataset tersebut merupakan kompilasi dari seluruh instance (baris data) dari sebelas bulan periode rekonsiliasi.

Setiap instance dalam dataset telah dimasukkan ke dalam klasifikasi berdasarkan hasil rekonsiliasi (OK atau SELISIH). Jumlah seluruh instance dalam dataset adalah 13.782 baris data (instance) yang terdiri dari 10.503 instance dengan 
klasifikasi hasil rekonsiliasi OK dan 3.279 instance diklasifikasikan pada kelas SELISIH.

\section{e. Transformasi Data (Data Formatting)}

Sebelum data siap untuk diolah dalam aplikasi WEKA yang digunakan sebagai aplikasi data mining dalam proses modelling, dataset ditransformasi ke dalam file extension ${ }^{*} \mathrm{csv}$ (comma demilited). Transformasi ini dilakukan karena aplikasi WEKA tidak menerima input file dalam bentuk ekstensi excel (.xlsx) sedangkan file dalam bentuk *csv merupakan salah satu ekstensi yang diterima sebagai input file. Proses transformasi data dilakukan dengan menyimpan ulang (save as) dataset dan memilih ekstensi ${ }^{*} \mathrm{csv}$. File ini kemudian diberi nama DATASET_RANGE _MINUS SATKER PERIODE BA Es.csv. File ini selanjutnya merupakan dataset yang telah siap untuk diinput dan diproses pada aplikasi WEKA.

Proses transformasi di atas dilakukan atas dataset sebelum diinput ke dalam aplikasi data mining yang digunakan. Namun dataset tersebut belum sepenuhnya siap untuk diolah dalam teknik data mining. Tahapan terakhir dalam formatting data (transformasi data) adalah memastikan bahwa tiap-tiap atribut telah sesuai dengan tipe datanya yaitu tipe numeric dan tipe nominal.

\subsection{Pemodelan (Modeling)}

Tahapan keempat dalam pendekatan teknik CRISP-DM adalah membuat model-model berdasarkan dataset yang telah dipersiapkan pada tahapan-tahapan sebelumnya. Pemodelan digunakan dengan menggunakan algoritma pohon keputusan (decision tree) C4.5. Sebagaimana diuraikan pada bagian sebelumnya, algoritma C4.5 dipilih karena merupakan algoritma yang paling umum dan memberikan akurasi dan kecepatan pemrosesan yang sangat baik. Dalam aplikasi WEKA algoritma C4.5 dikenal dengan nama J48 decision tree.

Pemodelan dilakukan dengan menggunakan dataset dengan file name DATASET_RANGE _MINUS SATKER PERIODE BA Es.csv. Aplikasi data mining yang digunakan adalah Weka versi 3.6.13 untuk membangun model-model dalam mengolah dataset.

Teknik data mining yang dilakukan dalam penelitian inimenggunakan teknik klasifikasi dengan menggunakan algoritma decision tree (pohon keputusan) C.45. Algoritma tersebut pada aplikasi WEKA dinamakan dengan algoritma J48. Kotsiantis (2007) mengutip hasil penelitian TjenSien et al. menyatakan bahwa algoritma C4.5 memiliki kombinasi tingkat kesalahan dan kecepatan pemrosesan yang baik.

Analisis penelitian didasarkan pada hasil mining model-model yang dibangun dari dataset yang telah disiapkan sebelumnya. Untuk mendukung tercapainya tujuan penelitian maka model-model tersebut dibagi ke dalam beberapa bagian yaitu model tanpa pemangkasan pada pohon keputusan (unpruned) dan model dengan pemangkasan pada pohon keputusan (pruned). Pemangkasan (pruning) terdiri dari dua jenis yaitu online pruning dan postpruning. Online pruning dilakukan pada saat proses klasifikasi berlangsung dan pohon keputusan disusun. Sedangkan postpruning adalah proses pemangkasan pada pohon keputusan saat proses klasifikasi telah selesai. Pemangkasan (pruning) dilakukan untuk mengecilkan pohon keputusan dari hasil data mining. Pohon keputusan yang terlalu besar akan menyulitkan pemahaman pola dan makna yang terbentuk.

Dengan membangun tiga belas model yang mencakup model tanpa pemangkasan (unpruning), model dengan prepruning, dan model-model dengan postpruning. Pengaturan parameterparameter yang membangun model dan hasil-hasil model ditunjukkan pada tabel berikut:

Tabel 9. Ringkasan Hasil Klasifikasi Model-Model

\begin{tabular}{|c|c|c|c|c|c|c|c|c|}
\hline No & $\begin{array}{l}\text { Nama } \\
\text { Model }\end{array}$ & $\begin{array}{l}\text { Correctly } \\
\text { Classified } \\
\text { Instances }\end{array}$ & $\begin{array}{l}\text { Kappa } \\
\text { Statistic }\end{array}$ & AUC & $\begin{array}{c}\text { Size } \\
\text { of } \\
\text { Tree }\end{array}$ & $\begin{array}{c}\text { Number of } \\
\text { Tree }\end{array}$ & Waktu & $\begin{array}{c}\mathrm{TP} \\
\text { rate }\end{array}$ \\
\hline 1 & $\begin{array}{c}\text { Model } \\
\text { M1 }\end{array}$ & $76,57 \%$ & 0,30 & 0,675 & 4.421 & 3.094 & 0,67 & 0,41 \\
\hline 2 & $\begin{array}{c}\text { Model } \\
\text { M2 }\end{array}$ & $77,14 \%$ & 0,28 & 0,73 & 962 & 696 & $\begin{array}{c}31,9 \\
3\end{array}$ & 0,34 \\
\hline 3 & $\begin{array}{c}\text { Model } \\
\text { M3 }\end{array}$ & $77,72 \%$ & 0,27 & 0,73 & 325 & 238 & 9,88 & 0,34 \\
\hline 4 & $\begin{array}{c}\text { Model } \\
\text { M4 }\end{array}$ & $78,10 \%$ & 0,24 & 0,71 & 113 & 85 & 2,25 & 0,24 \\
\hline 5 & $\begin{array}{c}\text { Model } \\
\text { M5 }\end{array}$ & $78,29 \%$ & 0,23 & 0,71 & 76 & 56 & 1,5 & 0,22 \\
\hline 6 & $\begin{array}{c}\text { Model } \\
\text { M6 }\end{array}$ & $78,03 \%$ & 0,22 & 0,71 & 73 & 53 & 1,33 & 0,21 \\
\hline 7 & $\begin{array}{c}\text { Model } \\
\text { M7 }\end{array}$ & $77,84 \%$ & 0,21 & 0,71 & 66 & 48 & 1,13 & 0,21 \\
\hline 8 & $\begin{array}{c}\text { Model } \\
\text { M8 }\end{array}$ & $78 \%$ & 0,22 & 0,71 & 51 & 36 & 1,14 & 0,21 \\
\hline 9 & $\begin{array}{l}\text { Model } \\
\text { M12 }\end{array}$ & $76,51 \%$ & 0,16 & 0,64 & 12 & 15 & 0,23 & 0,17 \\
\hline 10 & $\begin{array}{c}\text { Model } \\
\text { M13 }\end{array}$ & $76,53 \%$ & 0,15 & 0,62 & 7 & 6 & 0,48 & 0,16 \\
\hline 11 & $\begin{array}{c}\text { Model } \\
\text { M9 }\end{array}$ & $77,18 \%$ & 0,30 & 0,68 & 2.295 & 1.565 & 0,63 & 0,38 \\
\hline 12 & $\begin{array}{l}\text { Model } \\
\text { M10 }\end{array}$ & $78,86 \%$ & 0,29 & 0,68 & 724 & 497 & 0,45 & 0,29 \\
\hline 13 & $\begin{array}{l}\text { Mode } \\
\text { l M11 }\end{array}$ & $78,71 \%$ & 0,25 & 0,68 & 349 & 239 & 0,42 & 0,24 \\
\hline
\end{tabular}

Sumber: Diolah dari Aplikasi WEKA

Dari seluruh model akurasi correctly classified dihasilkan oleh model M10 dengan akurasi $78,86 \%$, nilai kappa statistic tertinggi 0,3 dihasilkan oleh model M9, nilai AUC tertinggi dihasilkan oleh model M3 dan M2 dengan nilai 0,73 , sedangkan TP rate paling besar dihasilkan dari model M11, ukuran pohon paling besar 
dihasilkan dari Model M11 dengan ukuran 11 dan paling kecil oleh Model M13 dengan ukuran pohon 7.

Tingkat correctly classified menunjukkan tingkat keberhasilan model dalam mengklasifikasikan data ke dalam kelas-kelas. Sedangkan nilau AUC (area under curve of ROC) menunjukkan suatu penilaian model berdasarkan kurva ROC di mana rentang nilai AUC dimulai dari 0 sampai dengan 1 . Gorunescu (2011) menyatakan bahwa nilai AUC dapat dikelompokkan ke dalam 5 kategori untuk memudahkan interpretasi dalam penilaian performa suatu model yang digambarkan dalam tabel berikut.

Tabel 8. Kategori Nilai AUC

\begin{tabular}{|c|c|}
\hline Nilai & Kategori (Classification) \\
\hline $0,9-1$ & Excellent \\
\hline $0,8-0,9$ & Good \\
\hline $0,7-0,8$ & Fair \\
\hline $0,6-0,7$ & Poor \\
\hline $0,5-0,6$ & Failure \\
\hline
\end{tabular}

Sumber: Gorunescu (2011).

Sedangkan ukuran kappa statistic diartikan sebagai tingkat keberhasilan kesepakatan (agreement) suatu model dalam menentukan hasil klasifikasi. Nilai kappa statistic berada pada rentang - 1 sampai dengan 1 di mana nilai -1 diartikan bahwa model tidak berhasil dalam menentukan kesepakatan hasil klasifikasi dan nilai 1 bahwa model sepenuhnya berhasil. Azis (2015) mengacu pada Vierra dan Joanne (2008) mengungkapkan bahwa nilai kappa statistic dapat diinterpretasikan ke dalam enam kategori yang diuraikan dalam tabel berikut. ${ }^{21}$

Tabel 10. Interpretasi Kappa Statistic

\begin{tabular}{|c|l|}
\hline Nilai & \multicolumn{1}{|c|}{ Interpretasi } \\
\hline$<0$ & Less than chance agrrement \\
\hline $0,01-0,20$ & Slight Agreement \\
\hline $0,21-0,40$ & Fair Agreement \\
\hline $0,41-0,60$ & Moderate Agreement \\
\hline $0,61-0,80$ & Substantial Agreement \\
\hline $0,81-0,99$ & Almost Perfect Agreement \\
\hline
\end{tabular}

Sumber: Vierra dan Joanne (2008).

Nilai kappa statistic di bawah 0,2 harus menjadi pertimbangan penting karena nilai kappa statistic pada rentang tersebut merupakan kategori

21 Saeful Azis, "Karakterisasi Satuan Kerja Terkait Inakurasi Perencanaan Kas Dengan Menggunakan Teknik Data Mining (Studi Kasus Satuan Kerja Lingkup Kanwil DJPBN Provinsi Bengkulu)", (Tangerang Selatan: PKN STAN, 2015). slight agreement. Dengan demikian, Model M12 dan M13 tidak dipilih menjadi model meski jumlah pohon yang dihasilkan merupakan ukuran pohon keputusan terkecil yaitu 12 dan 7. Demikian juga dengan nilai AUC di bawah 7 yang merupakan kategori poor classification tidak dipilih. Seluruh model yang dibangun dengan postpruning menghasilkan nilai AUC di bawah 7. Ukuran pohon keputusan yang dihasilkan model-model tersebut juga masih dalam ukuran yang sangat besar. Dengan demikian model M9, M10, M11, M12, dan M13 dikeluarkan dari kandidat model yang akan dipilih sehingga tersisa tujuh model yang masih akan dibandingkan. Ketujuh kandidat tersebut diuraikan secara jelas pada tabel 11.

Berdasarkan penilaian tersebut, penulis memilih model M8 yang menunjukkan kinerja hasil pengklasifikasian dengan akurasi yang baik dibandingkan dengan model-model lainnya. Model M8 menghasilkan tingkat correctly classified $78 \%$, nilai AUC 0,71, kappa statistic 0,22, dan dengan ukuran pohon keputusan paling kecil dari tujuh kandidat model.

\section{a. Pemilihan Model}

Dari seluruh model akurasi correctly classified dihasilkan oleh model M10 dengan akurasi $78,86 \%$, nilai kappa statistic tertinggi 0,3 dihasilkan oleh model M9, nilai AUC tertinggi dihasilkan oleh model M3 dan M2 dengan nilai 0,73 , sedangkan TP rate paling besar dihasilkan dari model M11, ukuran pohon paling besar dihasilkan dari Model M11 dengan ukuran 11 dan paling kecil oleh Model M13 dengan ukuran pohon 7.

Nilai kappa statistic di bawah 0,2 harus menjadi pertimbangan penting karena nilai kappa statistic pada rentang tersebut merupakan kategori slight agreement. Dengan demikian, Model M12 dan M13 tidak dipilih menjadi model meski jumlah pohon yang dihasilkan merupakan ukuran pohon keputusan terkecil yaitu 12 dan 7. Demikian juga dengan nilai AUC di bawah 7 yang merupakan kategori poor classification tidak dipilih. Seluruh model yang dibangun dengan postpruning menghasilkan nilai AUC di bawah 7. Ukuran pohon keputusan yang dihasilkan model-model tersebut juga masih dalam ukuran yang sangat besar. Model M9, M10, M11, M12, dan M13 dikeluarkan dari kandidat model yang akan dipilih sehingga tersisa tujuh model yang masih akan dibandingkan. Ketujuh kandidat tersebut diuraikan secara jelas pada tabel berikut. 
Tabel 11. Kandidat Model Terpilih

\begin{tabular}{|c|c|c|c|c|c|c|c|c|}
\hline No & Model & $\begin{array}{c}\text { Correctly } \\
\text { Classified } \\
\text { Instances }\end{array}$ & $\begin{array}{c}\text { Kappa } \\
\text { Statistic }\end{array}$ & AUC & $\begin{array}{c}\text { Size } \\
\text { of } \\
\text { Tree }\end{array}$ & $\begin{array}{c}\text { Number } \\
\text { of Tree }\end{array}$ & Waktu & $\begin{array}{c}\text { TP } \\
\text { rate }\end{array}$ \\
\hline 1 & $\begin{array}{c}\text { Model } \\
\text { M2 }\end{array}$ & $77,14 \%$ & 0,28 & 0,73 & 962 & 696 & 31,93 & 0,34 \\
\hline 2 & $\begin{array}{c}\text { Model } \\
\text { M3 }\end{array}$ & $77,72 \%$ & 0,27 & 0,73 & 325 & 238 & 9,88 & 0,34 \\
\hline 3 & $\begin{array}{c}\text { Model } \\
\text { M4 }\end{array}$ & $78,10 \%$ & 0,24 & 0,71 & 113 & 85 & 2,25 & 0,24 \\
\hline 4 & $\begin{array}{c}\text { Model } \\
\text { M5 }\end{array}$ & $78,29 \%$ & 0,23 & 0,71 & 76 & 56 & 1,5 & 0,22 \\
\hline 5 & $\begin{array}{c}\text { Model } \\
\text { M6 }\end{array}$ & $78,03 \%$ & 0,22 & 0,71 & 73 & 53 & 1,33 & 0,21 \\
\hline 6 & $\begin{array}{c}\text { Model } \\
\text { M7 }\end{array}$ & $77,84 \%$ & 0,21 & 0,71 & 66 & 48 & 1,13 & 0,21 \\
\hline 7 & $\begin{array}{c}\text { Model } \\
\text { M8 }\end{array}$ & $78 \%$ & 0,22 & 0,71 & 51 & 36 & 1,14 & 0,21 \\
\hline
\end{tabular}

Sumber: Diolah dari Aplikasi WEKA

Berdasarkan penilaian tersebut, penulis memilih model M8 yang menunjukkan kinerja hasil pengklasifikasian dengan akurasi yang baik dibandingkan dengan model-model lainnya. Model M8 menghasilkan tingkat correctly classified 78\%, nilai AUC 0,71, kappa statistic 0,22, dan dengan ukuran pohon keputusan paling kecil dari tujuh kandidat model.

\section{b. Evaluasi Terhadap Model}

Model M8 menghasilkan nilai AUC sebesar 0,71 di mana angka tersebut dikategorikan sebagai fair classification. Kappa statistic juga menjadi pertimbangan penting yang harus diperhatikan. Model M8 menghasilkan nilai kappa statistic 0,22 di mana nilai tersebut dapat diterima karena tergolong dalam kategori fair agreement. Faktor yang paling dipertimbangkan adalah ukuran pohon keputusan yang dihasilkan. Hal ini untuk memastikan bahwa ukuran pohon keputusan model yang dipilih cukup ramping untuk dianalisis demi tercapainya tujuan penelitian. Model M8 adalah model dengan ukuran pohon paling kecil di antara ketujuh kandidat dengan nilai 51.

Confucious matrix menunjukkan bahwa model M8 berhasil mengklasifikasikan 10.038 instance pada kelas $\mathrm{OK}$ dan 465 instance tidak tepat diklasifikasikan. Pada kelas SELISIH sebanyak 715 instance berhasil diklasifikasikan pada kelas SELISIH dan 2.564 tidak tepat. Pengklasifikasian dalam kelas ini dapat dikatakan masih cukup baik di mana nilai kappa statistic yang masih dikategorikan sebagai fair agreement. Hasil True Positive (TP) pada kelas SELISIH adalah 0,21.

\section{c. Evaluasi Pola (Pattern Evaluation)}

Model yang dipilih yaitu model M8 menghasilkan pohon keputusan dengan ukuran 51 dan jumlah daun sebanyak 36. Dibandingkan dengan model-model lainnya model M8 adalah model yang membentuk pohon keputusan dengan ukuran paling ramping.

Atribut-atribut yang menjadi faktor dalam penyusunan pohon keputusan model M8 antara lain jumlah SP2D, Status PNBP, Jumlah Program, Jumlah Output, Tipe Dekonsentrasi, Besaran Pagu, dan Realisasi Belanja Barang. Atribut-atribut yang tidak membangun pohon keputusan model M8 merupakan atribut-atribut yang tidak berpengaruh signifikan.

Atribut baris pertama dari pohon keputusan yang terbentuk adalah atribut Jumlah SP2D. Dengan berada pada baris pertama pada pohon keputusan, atribut SP2D merupakan atribut yang menjadi akar pohon yang menjadi titik awal penentuan klasifikasi OK dengan SELISIH.

Berdasarkan Gambar 5.1, jumlah SP2D dalam pohon keputusan terbagi menjadi dua nilai yaitu jumlah SP2D $<49$ dan Jumlah SP2D > 49. Cabang pertama dari cabang SP2D (< 49) adalah Status PNBP. Sementara cabang kedua dari SP2D (> 49) menuju dua cabang berikutnya yaitu SP2D berjumlah 49 sampai dengan 373 dan jumlah SP2D lebih dari 373. Jumlah SP2D yang lebih dari 373 langsung diklasifikasikan sebagai satker SELISIH. Sementara cabang jumlah SP2D 49 s.d. 373 menuju ke cabang Atribut Realisasi Belanja Sosial (57). Bila realisasi belanja sosial (57) berlabel ADA maka diklasifikasikan sebagai SELISIH. Bila tidak ada realisasi belanja 57 maka cabang berikutnya adalah PNBP.

Gambar 1. Potongan 1 Pohon Keputusan Model M8

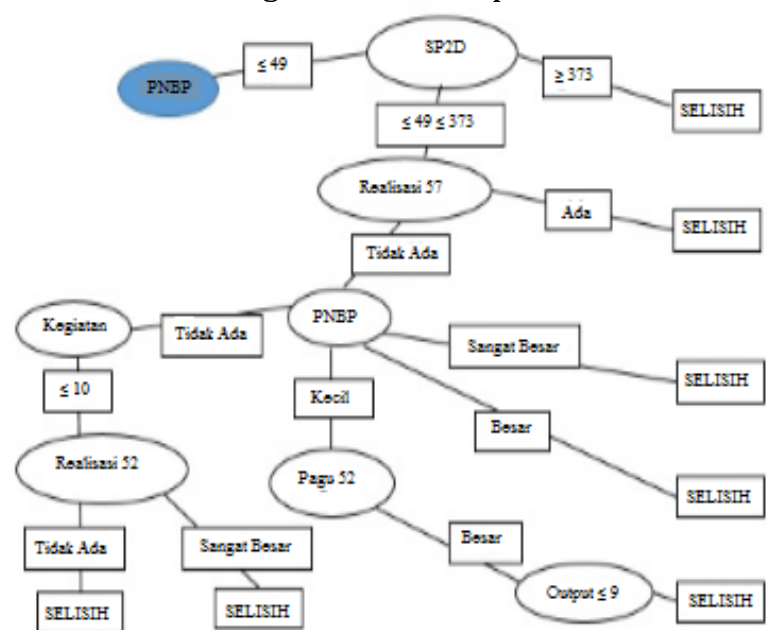

Sumber: Diolah dari Aplikasi WEKA

Satker (instances) dengan realisasi PNBP sangat besar dan besar langsung diklasifikasikan pada SELISIH. Sementara itu PNBP dengan realisasi KECIL kemudian diuji dengan besaran pagu belanja barang (52). Satker (instances) dengan pagu Besar dan Output kurang dari 9 diklasifikasikan pada SELISIH. Selanjutnya satker dengan realisasi PNBP berlabel TIDAK ADA, selanjutnya masuk pohon penguji atribut jumlah kegiatan. Bilamana jumlah kegiatan lebih kecil dari 10, realisasi Belanja Barang berlabel SANGAT BESAR dan berlabel TIDAK ADA maka diklasifikasikan pada SELISIH. Potongan kedua dari pohon keputusan dijelaskan pada gambar. 
Atribut kedua pada pohon keputusan model M8 memunculkan atribut PNBP di mana atribut ini membentuk dua cabang potensial yang akan membentuk klasifikasi SELISIH. Cabang kanan membuat pola realisasi PNBP dalam jumlah SEDANG dan jumlah program $>1$ maka akan membentuk klasifikasi SELISIH. Cabang tengah memulai pola dengan realisasi PNBP dalam jumlah KECIL dan program $>1$ dan output $>5$ maka akan menuju kelas SELISIH. Cabang ketiga yaitu PNBP tanpa realisasi maka menguji atribut program.

\section{Gambar 2. Potongan 2 Pohon Keputusan Model M8}

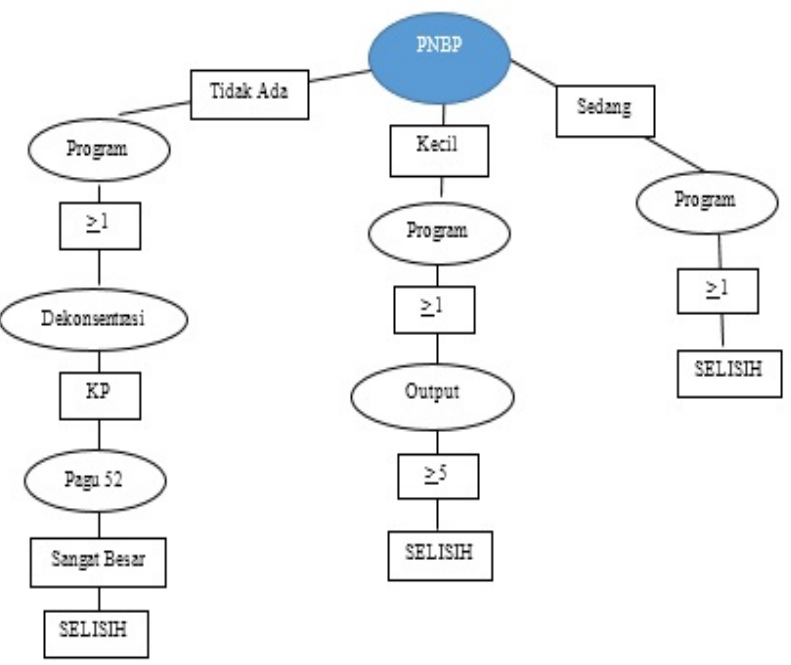

Sumber: Diolah dari Aplikasi WEKA

Bila jumlah program > 1 maka selanjutnya menguji jenis dekonsentrasi di mana yang berpeluang untuk masuk pada kelas SELISIH adalah jenis dekonsentrasi KP. Satker KP dengan pagu belanja barang sangat besar akan diklasifikasikan pada klasifikasi SELISIH.

Berdasarkan pohon keputusan dapat disimpulkan bahwa dua atribut yang paling berpengaruh adalah jumlah SP2D dan realisasi PNBP. Jumlah SP2D dan realisasi PNBP yang besar cenderung meningkatkan kemungkinan terjadinya selisih rekonsiliasi karena dengan semakin banyaknya data yang harus direkam pada sistem akuntansi satker melalui aplikasi maka semakin besar pula kemungkinan terjadinya kesalahan.

\section{KESIMPULAN DAN SARAN}

\subsection{Kesimpulan}

Berdasarkan hasil penelitian dan pembahasan pada bagian sebelumnya, penulis menarik beberapa simpulan yaitu:

1. Dalam menemukan karakterisasi satuan kerja yang mempunyai selisih pada hasil rekonsiliasinya, dibangun 13 model. 13 model ini dibangun untuk menemukan faktor-faktor yang mempengaruhi proses rekonsiliasi dan menemukan karakterisasi satker yang hasil rekonsiliasinya selisih. Seluruh model dibangun berdasarkan tiga metode pemrosesan yaitu tanpa pemangkasan (1 model), pemangkasan pada saat penyusunan pohon keputusan sedang berlangsung (onlinepruning) dengan jumlah model sebanyak 9 model, dan postpruning (3 model).

Model yang dipilih dari 13 model yang telah disusun adalah model M8 dengan tingkat akurasi correctly classified sebesar 78\%, nilai kappa statistic 0,22, dan nilai AUC sebesar 0,71. Berdasarkan nilai kappa statistic dan nilai AUC model ini dikategorikan sebagai fair agreement dan fair classification. Ukuran pohon yang dihasilkan oleh model M8 cukup ramping untuk dilakukan analisis yaitu dengan ukuran 51 dan jumlah daun 36.

Atribut-atribut yang mempengaruhi pengklasifikasian proses rekonsiliasi dapat dianalisis berdasarkan pohon keputusan model M8. Atribut yang paling berpengaruh adalah jumlah SP2D satuan kerja diikuti dengan besaran realisasi PNBP dan atribut Jumlah Program. Atribut-atribut lain seperti Jenis Dekonsentrasi, Realisasi Belanja Bantuan Sosial (57), Jumlah Kegiatan, Jumlah Output, dan Besaran Pagu Belanja Barang (52) membentuk cabang pada posisi di tengah pohon keputusan yang menunjukkan bahwa pengaruh atribut-atribut tersebut tidak besar.

Dua atribut yang paling mempengaruhi terjadinya selisih rekonsiliasi berdasarkan pohon keputusan yang terbentuk adalah atribut jumlah SP2D dan nilai realisasi PNBP. Semakin banyak SP2D dan semakin besar nilai realisasi PNBP yang harus dicatat pada sistem akuntansi satker melalui aplikasi maka kecenderungan terjadinya kesalahan pencatatan semakin tinggi.

2. Berdasarkan pohon keputusan yang dihasilkan oleh model M8, karakteristik satker dengan kecenderungan mendapatkan selisih dalam proses rekonsiliasi antara lain:

a. Satker dengan jumlah SP2D $<45$, memiliki realisasi PNBP 1 juta sampai dengan 100 juta, program $>1$, dan output. Satker dengan jumlah SP2D $<45$ dengan realisasi PNBP 100 juta sampai dengan 1 miliar dan program yang dimiliki satker lebih dari 1 .

b. Satker dengan jumlah SP2D $<45$, realisasi PNBP 0, Jumlah Program Satuan kerja $>1$, Jenis Dekonsentrasi KP (Kantor Pusat), dan Pagu Belanja Barang sebesar > 500 miliar. Satker dengan jumlah SP2D 45 sampai dengan 373 dan memiliki realisasi 
belanja bantuan sosial. Satker dengan jumlah SP2D antara 45 sampai dengan 373, realisasi PNBP 1 juta sampai dengan 100 juta, memiliki pagu belanja barang 10 miliar sampai dengan 100 miliar, dan jumlah output $<$ 9. Satker dengan jumlah SP2D 45 sampai dengan 373, realisasi belanja bantuan sosial 0 , realisasi PNBP 0 , dan output $<9$.

c. Satker-satker yang memiliki jumlah SP2D yang banyak (jumlah SP2D lebih dari 373).

\subsection{Saran}

Model M8 dapat diterapkan dalam mendukung tugas dan fungsi KPPN terkait penyusunan Laporan Keuangan Pemerintah Pusat (LKPP) yang didahului dengan proses rekonsiliasi yang benar. Model M8 dapat menjelaskan atributatribut yang paling mempengaruhi terjadinya selisih pada hasil rekonsiliasi. Model ini dapat menghasilkan karakterisasi satuan kerja yang cenderung selisih hasil rekonsiliasinya. Dengan model M8, KPPN selaku unit vertikal Dijten Perbendaharaan Kementerian Keuangan dapat memaksimalkan fungsi supervisi, pembinaan, serta monitoring dalam pelaksanan rekonsiliasi dan penyusunan LKPP dengan cara memfokuskan pelaksanaan fungsi-fungsi tersebut kepada satkersatker sesuai dengan karakterisasi model M8.

Terkait pelaksanaan rekonsiliasi pada akhir tahun dan penyusunan LKPP tahunan, KPPN dapat menggunakan model M8 sebagai dasar dalam penentuan satker-satker yang menjadi fokus pembinaan supervisi, bimbingan teknis, dan sosialisasi dalam menghadapi langkah-langkah akhir tahun. Penerapan model M8 ini sebaiknya digunakan untuk menetapkan satker tujuan dalam rangkaian perjalanan dinas akhir tahun terkait pelaksanaan rekonsiliasi dan penyusunan laporan keuangan.

Dalam menetapkan satker-satker yang menjadi peserta dalam kegiatan sosialisasi langkah-langkah dalam menghadapi tahun anggaran, model M8 dapat membantu KPPN dalam penentuan satker-satker yang selanjutnya akan menjadi fokus pembinaan. Dengan teridentifikasinya satker-satker dimaksud, KPPN dapat melakukan aktivitas prarekonsiliasi dengan satker. Prarekonsiliasi ini dapat dilakukan dengan konfirmasi jumlah SP2D yang terbit dalam suatu periode, jenis-jenis SP2D yang telah terbit, nilai rupiah SP2D, lokasi bank penyetoran penerimaan negara, batas akhir penyetoran tahun anggaran berjalan, dan jumlah setoran dan rupiah penerimaan negara (SSBP/SSPB). Pada akhirnya kegiatan-kegiatan prarekonsiliasi akan membantu KPPN dalam mencegah terjadinya selisih hasil rekonsiliasi data keuangan dan akan mendukung penyusunan LKPP yang memenuhi karakteristik kualitatif akurat dan andal.

Penulis menyarankan agar dalam penerapan model M8 didasarkan pada pengaturan parameter dan dataset sebagaimana dalam penelitian ini. Hal tersebut dilakukan agar penerapan model M8 dapat menghasilkan kinerja pengklasifikasian yang baik dalam penentuan satker-satker yang menjadi fokus pembinaan dan supervisi.

Model M8 hanya dibangun berdasarkan atribut-atribut yang tersedia dalam sumber database. Atribut-atribut tersebut pada dasarnya bagian dari identitas tiap-tiap satker dan hasil realisasi pelaksanaan anggaran. Bagi para peneliti selanjutnya hendaknya menambah atribut-atribut lainnya di luar atribut-atribut terkait pelaksanaan anggaran, seperti atribut umur operator aplikasi, lama bertugas, tingkat pengetahuan IT operator, jenis pelaksanaan rekonsiliasi (via email/ datang langsung), dan atribut-atribut lain yang relevan. Penulis juga memandang perlunya peneliti-peneliti selanjutnya untuk memperluas ruang lingkup objek penelitan baik dengan memperbesar rentang periode pelaksanaan rekonsiliasi maupun dengan memperluas lingkup objek penelitian dengan meliputi unit-unit lain di luar Kanwil Ditjen Perbendaharaan Provinsi Jakarta.

\section{IMPLIKASI DAN KETERBATASAN}

Penelitian ini memiliki beberapa keterbatasan. Penggunaan data dalam jumlah yang sangat besar berpeluang menimbulkan kesalahan dalam proses persiapan data menjadi dataset penelitian. Selain itu data penelitian yang digunakan dalam penelitian menghilangkan beberapa data tanpa atribut identitas (kode satker) sebagaimana adanya data dari database SPAN.

Penelitian ini juga terbatas pada ruang lingkup waktu penelitian. Objek penelitian pelaksanaan rekonsiliasi hanya mencakup periode bulan Januari s.d. November 2015 dan tidak mencakup pelaksanaan rekonsiliasi periode Desember 2015.

Keterbatasan-keterbatasan yang disebutkan di atas dapat menyebabkan perbedaan hasil dalam pemodelan dalam data mining sehingga model yang terpilih juga berbeda dengan hasil penelitian ini. Model terpilih yang berbeda akan menyebabkan perbedaan faktor-faktor dan karakterisasi satuan kerja dengan hasil penelitian ini. Perbedaan hasil dalam pemodelan selanjutnya menyebabkan perbedaan pengaturan parameterparameter dalam model yang terpilih. Hal ini menyebabkan penerapan model terpilih dalam tataran praktis dapat berimplikasi pada hasil yang bias. 
Penelitian selanjutnya diharapkan dapat meminimalkan kesalahan dalam persiapan data untuk mencegah bias hasil penelitian. Penulis juga menyarankan kepada para peneliti selanjutnya untuk memperluas objek penelitian baik dengan memperluas cakupan satuan kerja maupun dengan memperpanjang seri waktu objek yang diteliti.

\section{PENGHARGAAN (ACKNOWLEDGEMENT)}

Penulis dengan segala keterbatasan pengetahuan dan pengalaman sangat terbantu atas peran serta berbagai pihak yang telah memberikan dukungan, saran, bimbingan dalam penulisan penelitian ini. Melalui tulisan ini, dengan kerendahan hati dan rasa hormat penulis mengucapkan terima kasih kepada pihak-pihak yang telah mendukung terlaksananya penelitian ini. Besar harapan penulis kiranya penelitian ini memberikan manfaat bagi pihak-pihak yang membacanya.

\section{DAFTAR PUSTAKA (REFERENCES)}

Azis, Saeful. (2015). Karakterisasi Satuan Kerja Terkait Inakurasi Perencanaan Kas Dengan Menggunakan Teknik Data Mining (Studi Kasus Satuan Kerja Lingkup Kanwil DJPBN Provinsi Bengkulu). Tangerang Selatan: PKN STAN

Baker, Ryan S.J.D. (2010). Data Mining for Education. Pennsylvania: Carnegie Mellon University.

Bramer, Max. (2007). Principles of Data Mining. Portsmouth: University Of Portsmouth.

Folorunso, 0. (2005). Data Mining as a Technique for Knowledge in Business Process Redesign. Proquest Health Management: Information Management \& Computer Security.

Gorunescu, Florin. (2011). Data Mining: Concepts, Models, and Techniques. Berlin: Springer.

Hermawan, Randy. (2015). Penggunaan Teknik Data Mining untuk Memprediksi Kondisi Financial Distress pada Pemerintah Daerah Kabupaten/ Kota di Indonesia. Tangerang Selatan: PKN-STAN.

Kotsiantis, S. B. (2007). Supervised Machine Leraning: A Review of Classification Techniques. Tripoli: University of Peloponnese.

Laporan Hasil Pemeriksaan BPK RI Atas Laporan Keuangan Pemerintah Pusat Tahun 2013.

Laporan Hasil Pemeriksaan BPK RI Atas Laporan Keuangan Pemerintah Pusat Tahun 2014
Modul SPAN dan SAKTI: Direktorat Jenderal Perbendaharaan.

Peraturan Menteri Keuangan Nomor 210 Tahun 2013 Tentang Pedoman Rekonsiliasi dalam Rangka Penyusunan Laporan Keuangan Lingkup Bendahara Umum Negara dan Kementerian Negara/ Lembaga.

Peraturan Menteri Keuangan Nomor 213 Tahun 2013 Tentang Sistem Akuntansi dan Pelaporan Keuangan Pemerintah Pusat.

Peraturan Menteri Keuangan Nomor 262 Tahun 2014 Tentang Sistem Akuntansi dan Pelaporan Keuangan Pemerintah Pusat.

Peraturan Menteri Keuangan Nomor 210 Tahun 2013 Tentang Pedoman Rekonsiliasi Dalam Rangka Penyusunan Laporan Keuangan Lingkup Bendahara Umum Negara dan Kementerian/ Lembaga.

Perdirjen Perbendaharaan Nomor 24 Tahun 2015 tentang Pedoman Pelaksanaan Penerimaan dan Pengeluaran Negara pada Akhir Tahun Anggaran 2015.

Pudjo, Prabowo Widodo, Rahmadya Trias Handayatno, \& Herlawati. (2013). Penerapan Data Mining Dengan Matlab. Bandung: Rekaya Sains.

Rokach, Lior dan O Maimon. (2005). Data Mining and Knowledge Discovery Handbook. Tel Aviv: Tel Aviv University.

Shearer, Colin. (2000). Journal of Data Mining. North Hollywood: The Data Warehousing Institute.

Tudor, Irina. (2008). Association Rule Mining as a Data Mining Technique. Bd Bucuresti: Universitatea Petrol-gaze din Ploiesti.

Wibowo, Priyo Dede. (2013). Analisis Faktor-Faktor yang Mempengaruhi Waktu Penyelesaian Rekonsiliasi Data SAI Satuan Kerja. Malang: Universitas Brawijaya.

Undang-Undang Nomor 17 tahun 2003 tentang Keuangan Negara.

Undang-Undang Nomor 1 tahun 2004 tentang Perbendaharaan Negara. 